\title{
Biological Activity of Ag and Cu Monometallic Nanoparticles and Ag-Cu Bimetallic Nanocomposites against Plant Pathogens and Seeds
}

\author{
Tinatin Doolotkeldieva ${ }^{(D)}{ }^{1}$ Saikal Bobusheva ${ }^{(D},{ }^{1}$ Zhanarbek Zhasnakunov ${ }^{(D)}{ }^{2}$ \\ and Abduraim Satybaldiev ${ }^{2}{ }^{2}$ \\ ${ }^{1}$ Department of Plant Protection, Kyrgyz-Turkish Manas University, Bishkek 720044, Kyrgyzstan \\ ${ }^{2}$ Faculty of Biology and Chemistry, Arabaev Kyrgyz State University, Bishkek 720026, Kyrgyzstan \\ Correspondence should be addressed to Tinatin Doolotkeldieva; tinatin.doolotkeldiyeva@manas.edu.kg
}

Received 27 July 2021; Revised 31 October 2021; Accepted 28 January 2022; Published 28 February 2022

Academic Editor: Ovidiu Ersen

Copyright ( 92022 Tinatin Doolotkeldieva et al. This is an open access article distributed under the Creative Commons Attribution License, which permits unrestricted use, distribution, and reproduction in any medium, provided the original work is properly cited.

\begin{abstract}
The antibacterial activities of silver (Ag) and copper $(\mathrm{Cu})$ monometallic and bimetallic nanoparticles (MNPs and BNPs) against the most economically important and common plant bacterial diseases in Kyrgyzstan were tested, as well as their phytotoxic effects on wheat and corn seeds. To achieve this, a range of $\mathrm{Ag}$ and $\mathrm{Cu}$ MNPs and BNPs were synthesized using different methods and were tested at different concentrations to compare their biological effects. The antibacterial activities of Ag and $\mathrm{Cu} \mathrm{MNPs}$ and $\mathrm{Ag}-\mathrm{Cu}$ BNPs against the plant pathogenic bacteria Erwinia amylovora, Pseudomonas syringae, and Pectobacterium carotovorum were evaluated. Of the three pathogens, Ps. syringae was found to be the most sensitive to NPs. The antimicrobial activities of the tested NPs showed significant positive correlations with the concentration; hence, there was a dose-dependent effect. Due to their antibacterial properties, these $\mathrm{Ag}-\mathrm{Cu}$ nanocomposites have high potential in plant protection applications.
\end{abstract}

\section{Introduction}

New materials (i.e., nanopowders, nanocomposites, and nanofibres) less than $100 \mathrm{~nm}$ in at least one dimension have been developed in the last decades. Due to their quantum size and a significant increase in the proportion of surface atoms compared to bulk materials, nanocomposites have unusual biological properties [1-3]. In particular, their antimicrobial properties allow them to be used in various human and industrial applications. The antimicrobial mechanisms of nanoparticles (NPs) are based on their penetrability, small size, chemical toxicity, and ability to damage the bacterial cell membrane and produce reactive oxygen species (considered the primary mechanism of action) [4,5]. Silver-based NPs (Ag NPs) are mainly used as bactericidal and bacteriostatic agents in medicine [6-12]. It has been shown that the antibacterial activity is due to Ag+ions, not metallic Ag [13].
Nanocomposites, consisting of Ag and chitosan, in the form of nanofilms for covering wounds have been used to treat infections caused by Staphylococcus aureus, Escherichia coli, and Pseudomonas aeruginosa $[14,15]$.

Copper NPs ( $\mathrm{Cu}$ NPs) are also garnering considerable interest for practical applications in various economic areas [16]. Their favourable characteristics include high electrical and melting points, low electrochemical migration, increased bioavailability, and relatively low production cost.

In contrast to ionic biogenic metals, NPs have prolonged action, are less toxic than metal salts, and can activate physiological and biochemical processes in plants [17]. Among the studied polymer nanocomposites, those containing Ag and $\mathrm{Cu}$ have the greatest potential for use in humans and for improving human health, for example, in the food industry, biomedicine, and water purification applications [4]. Studies have shown that $\mathrm{Cu}$ NPs exhibit high cytotoxic 
activity against Gram-negative (E. coli) and Gram-positive (Bacillus subtilis) bacteria compared with gold NPs (Au NPs) [18].

The antibacterial activity of nanocomposites containing $\mathrm{Cu}$ NPs in cellulose was studied against pathogenic human bacteria, such as $S$. aureus and Klebsiella pneumonia. It was found that the chemical nature and morphology of the nanomillers had a significant influence on the antibacterial activity; the higher the $\mathrm{Cu}$ content in the composition, the greater the antibacterial activity [19]. In another study, Cu NPs at $70 \mathrm{ppm}$ were used to control fire blight disease in pear seedlings under greenhouse conditions. Treatment with $\mathrm{Cu}$ NPs led to increased morphological and physiological characteristics of the trees and improved fruit yield [20].

Nanocomposites of stabilized binary metal systems, combining the unique properties of different metal particles, have several qualities that are absent from materials that consist of one metal particle. Bimetallic NPs (BNPs) have drawn greater interest than monometallic NPs (MNPs) from scientific and technological perspectives [21-23].

The application of NPs is constantly expanding, and some attempts have been made to use them in agriculture, especially as potent antimicrobial agents for seed dressing $[24,25]$. The effect of Ag nanocomposites based on humic substances and their precursors on the potato plant pathogen Clavibacter michiganensis subsp. sepedonicum strain Ac-1405 was studied [26]. With the dearth of published research on NPs in agriculture, it is evident that the potential use of NPs in agriculture as antimicrobial agents to combat plant phytopathogens remains largely unexplored. Moreover, the interactions of metal NPs with plant cells are poorly understood; the effects of NPs on plant cells when NPs are used as plant protection agents are unclear. There are scant data on the negative effect of metal NPs on seed germination, root elongation, and vegetable crops' biomass $[2,27,28]$. Such knowledge and data gaps lead to a misunderstanding of how NPs are transmitted and accumulated at various levels of the food chain [29].

This research is aimed at studying the biological activity of MNPs ( $\mathrm{Ag}$ and $\mathrm{Cu}$ ) and BNPs $(\mathrm{Ag}-\mathrm{Cu})$ against the most economically important and common plant bacterial diseases in Kyrgyzstan and the phytotoxic effect on wheat and corn seeds. To achieve this goal, a range of Ag and $\mathrm{Cu}$ MNPs and BNPs were synthesized using different methods and were tested at different concentrations to compare their biological effects.

\section{Materials and Methods}

2.1. Synthesis of the Ag and Cu MNPs. The Ag and Cu MNPs used in this study were synthesized at the Faculty of Biology and Chemistry, Arabaev Kyrgyz State University. Tables 1-3 show the chemical formulations and synthesis methodologies of the $\mathrm{Ag}$ and $\mathrm{Cu}$ MNPs [30, 31].

2.2. Synthesis and Composition of the $\mathrm{Ag}$ and $\mathrm{Cu}$ BNPs in Various Media. Promising materials include nanostructured composites stabilized by polymeric substances in aqueous solutions, which hinder NP aggregation. To obtain a nano- composite of $\mathrm{Ag}$ and $\mathrm{Cu}$, chemical reduction in the presence of a stabilizer was performed. This method is simple and allows control of particle dispersion and morphology and, consequently, the properties of the final products. The solutions were prepared from chemically pure-grade silver nitrate $\left(\mathrm{AgNO}_{3}\right)$ and crystalline hydrate of copper sulphate $\left(\mathrm{CuSO}_{4} \cdot 5 \mathrm{H}_{2} \mathrm{O}\right)$. Gelatin was used to stabilize the BNPs as an efficient and environmentally safe material. A gelatin solution was added to a salt solution of $\mathrm{Ag}$, and a solution of hydrazine hydrate $\mathrm{N}_{2} \mathrm{H}_{4} \cdot \mathrm{H}_{2} \mathrm{O}$ served as a reducing agent.

The total reaction volume for the synthesis was $100 \mathrm{ml}$, which contained a mixture of aqueous $\mathrm{Ag}$ and $\mathrm{Cu}$ solution $\left(C_{\mathrm{Ag}+}=0.05 \mathrm{H}\right.$ and $\left.\mathrm{C}_{\mathrm{Cu}}{ }^{2+}=0.05 \mathrm{H}\right)$. A stabilizer and ammonia solution were added until $\mathrm{pH}=11$. The solution was heated, and then hydrazine hydrate was added in an amount exceeding the quantity of $\mathrm{Ag}$ and $\mathrm{Cu}$ ions.

The redox potential of hydrazine depends on the $\mathrm{pH}$ of the solution and has a more negative value in an alkaline medium $(-1.15 \mathrm{~V}$ at $\mathrm{pH}=14)$. For this reason, the synthesis was carried out in the presence of ammonia [11, 12].

The synthesis of the $\mathrm{Ag}$ and $\mathrm{Cu}$ BNPs was carried out in neutral $(\mathrm{pH}=7)$, acidic $(\mathrm{pH}=6)$, ammonia $(\mathrm{pH}=11)$, and alkaline $(\mathrm{NaOH}, \mathrm{pH}=11)$ media in the presence or absence of a stabilizer (Table 4).

The reduction products were separated from the liquid phase and washed using centrifugation until neutral $\mathrm{pH}$ was reached. The resulting product was dried in a drying oven at $55-60^{\circ} \mathrm{C}$

The resulting products were characterized on a RINT$2500 \mathrm{HV}$ diffractometer using filtered $\mathrm{Cu}$ radiation and a JOEL JSM-7600F emission scanning electron microscope (Kumamoto University, Japan). The BNPs were then tested at different $\mathrm{pH}$ values and concentrations, as indicated in Table 5.

2.3. Plant Pathogens. The following plant pathogens were used to test the antibacterial activity of the MNPs and BNPs: Erwinia amylovora (the causative agent of bacterial blight in apple and pear trees); Pseudomonas syringae (the causative agent of bacterial canker in fruit trees); and Pectobacterium carotovorum (the causative agent of soft rot in vegetable crops). The collection cultures of these pathogens isolated from diseased plants were preserved in meat peptone broth (MPB) at $-18^{\circ} \mathrm{C}$.

2.4. In Vitro Screening of Biological Activity of the MNPs and $B N P s$. The well diffusion method was used to estimate the antimicrobial activity of the MNPs and BNPs. The test cultures were grown on nutrient agar for 20-24h; then, a suspension was prepared in a $0.9 \%$ sodium chloride solution according to the turbidity standard for 10 units $\left(1 \times 10^{9} \mathrm{CFU} / \mathrm{ml}\right)$. Then, the bacterial culture was thoroughly mixed in molten nutrient agar medium and incubated at $27^{\circ} \mathrm{C}$. After colony growth, holes ( $5 \mathrm{~mm}$ diameter) were made using a sterile metal drill under aseptic conditions. One $\mathrm{ml}$ of $\mathrm{MNP}$ or BNP solution (at different $\mathrm{pH}$ ) was added to each well, and the Petri dishes with the cultures were incubated at $28^{\circ} \mathrm{C}$. In the control, nystatin was used in the form of a $1.0 \%$ solution. 
TABLE 1: The chemical formulations and synthesis methods of the Ag MNPs used in this study.

\begin{tabular}{|c|c|c|}
\hline $\begin{array}{l}\text { Sample } \\
\text { no. }\end{array}$ & Chemical formulation & Synthesis method \\
\hline $\begin{array}{l}\text { Sample } \\
I^{\circ}\end{array}$ & $\begin{array}{l}\text { Ag- } \mathrm{H}_{2} \mathrm{O} \text {-ERD (electrical erosion } \\
\quad \text { in distilled water) }\end{array}$ & $\begin{array}{l}\text { The Ag nanopowder was derived using the electrical erosion method, in the presence of } \\
\text { distilled water. }\end{array}$ \\
\hline $\begin{array}{l}\text { Sample } \\
\text { II }^{\circ}\end{array}$ & Ag- $\mathrm{H}_{2} \mathrm{O}$-gelatin, ERD & $\begin{array}{l}\text { The Ag nanopowder was synthesized using the electrical erosion method with a mixture of } \\
0.2 \% \text { gelatin. }\end{array}$ \\
\hline $\begin{array}{l}\text { Sample } \\
\text { III }^{\circ}\end{array}$ & & $\begin{array}{l}\text { The Ag nanopowder was derived using the chemical recovery method with hydrazine at a } \\
\text { neutral } \mathrm{pH} \text {. The Ag nanopowder was extracted before the first reaction. }\end{array}$ \\
\hline $\begin{array}{l}\text { Sample } \\
\text { IV }^{\circ}\end{array}$ & $\mathrm{Ag}-\mathrm{NH}_{4} \mathrm{OH}-$ & $\begin{array}{l}\text { The Ag nanopowder was derived using the chemical recovery method with hydrazine in the } \\
\text { presence of ammonia. Then, the Ag powders were washed to reach neutral } \mathrm{pH} \text {. }\end{array}$ \\
\hline $\begin{array}{l}\text { Sample } \\
\mathrm{V}^{\circ}\end{array}$ & $\mathrm{Ag}-\mathrm{H}_{2} \mathrm{O}$-gelatin & $\begin{array}{l}\text { At neutral } \mathrm{pH} \text {, the chemical recovery method was used to derive the Ag nanopowder in a } \\
\qquad 0.2 \% \text { gelatin. }\end{array}$ \\
\hline $\begin{array}{l}\text { Sample } \\
\mathrm{VI}^{\circ}\end{array}$ & Ag- $\mathrm{NH}_{4} \mathrm{OH}$-gelatin & $\begin{array}{l}\text { The Ag nanopowder was derived using the chemical recovery method with } 0,25 \% \text { gelatin in } \\
\text { ammonium reaction. }\end{array}$ \\
\hline
\end{tabular}

TABLE 2: The concentration of Ag MNPs derived in different synthesis ways.

\begin{tabular}{|c|c|c|c|c|c|}
\hline $\mathrm{I}^{\circ}-\mathrm{Ag}-\mathrm{H}_{2} \mathrm{O}-\mathrm{ERD}$ & $\mathrm{II}^{\circ}$-Ag- $\mathrm{H}_{2} \mathrm{O}$ gelatin- ERD & $\mathrm{III}^{\circ}-\mathrm{Ag}-\mathrm{H}_{2} \mathrm{O}$ & $\mathrm{IV}^{\circ}-\mathrm{Ag}-\mathrm{NH}_{4} \mathrm{OH}$ & $\mathrm{V}^{\circ}$-Ag- $\mathrm{H}_{2} \mathrm{O}$-gelatin & $\mathrm{VI}^{\circ}$ - Ag- $\mathrm{NH}_{4} \mathrm{OH}$ gelatin \\
\hline $\mathrm{I}^{\circ}-1-5 \mathrm{mg} / \mathrm{ml}$ & $\mathrm{II}^{\circ}-1-5 \mathrm{mg} / \mathrm{ml}$ & III $^{\circ}-1-5 \mathrm{mg} / \mathrm{ml}$ & $\mathrm{IV}^{\circ}-1-5 \mathrm{mg} / \mathrm{ml}$ & $\mathrm{V}^{\circ}-1-5 \mathrm{mg} / \mathrm{ml}$ & $\mathrm{VI}^{\circ}-1-5 \mathrm{mg} / \mathrm{ml}$ \\
\hline $\mathrm{I}^{\circ}-2-1 \mathrm{mg} / \mathrm{ml}$ & $\mathrm{II}^{\circ}-2-1 \mathrm{mg} / \mathrm{ml}$ & III $^{\circ}-2-1 \mathrm{mg} / \mathrm{ml}$ & $\mathrm{IV}^{\circ}-2-1 \mathrm{mg} / \mathrm{ml}$ & $\mathrm{V}^{\circ}-2-1 \mathrm{mg} / \mathrm{ml}$ & $\mathrm{VI}^{\circ}-2-1 \mathrm{mg} / \mathrm{ml}$ \\
\hline $\mathrm{I}^{\circ}-3-0.5 \mathrm{mg} / \mathrm{ml}$ & $\mathrm{II}^{\circ}-3-0.5 \mathrm{mg} / \mathrm{ml}$ & III $^{\circ}-3-0.5 \mathrm{mg} / \mathrm{ml}$ & $\mathrm{IV}^{\circ}-3-0.5 \mathrm{mg} / \mathrm{ml}$ & $\mathrm{V}^{\circ}-3-0.5 \mathrm{mg} / \mathrm{ml}$ & $\mathrm{VI}^{\circ}-3-0.5 \mathrm{mg} / \mathrm{ml}$ \\
\hline $\mathrm{I}^{\circ}-4-0.1 \mathrm{mg} / \mathrm{ml}$ & $\mathrm{II}^{\circ}-4-0.1 \mathrm{mg} / \mathrm{ml}$ & $\mathrm{III}^{\circ}-4-0.1 \mathrm{mg} / \mathrm{ml}$ & $\mathrm{IV}^{\circ}-4-0.1 \mathrm{mg} / \mathrm{ml}$ & $\mathrm{V}^{\circ}-4-0.1 \mathrm{mg} / \mathrm{ml}$ & $\mathrm{VI}^{\circ}-4-0.1 \mathrm{mg} / \mathrm{ml}$ \\
\hline
\end{tabular}

TABle 3: Different synthesized methods of Cu MNP samples at different concentrations.

\begin{tabular}{|c|c|c|c|c|c|}
\hline $\mathrm{I}^{\circ}-\mathrm{Cu}-\mathrm{H}_{2} \mathrm{O}-\mathrm{ERD}$ & $\mathrm{II}^{\circ}-\mathrm{Cu}-\mathrm{H}_{2} \mathrm{O}$ gelatin-ERD & $\mathrm{III}^{\circ}-\mathrm{Cu}-\mathrm{H}_{2} \mathrm{O}$ & $\mathrm{IV}^{\circ}-\mathrm{Cu}-\mathrm{NH}_{4} \mathrm{OH}$ & $\mathrm{V}^{\circ}-\mathrm{Cu}-\mathrm{H}_{2} \mathrm{O}$-gelatin & $\mathrm{VI}^{\circ}-\mathrm{Cu}-\mathrm{NH}_{4} \mathrm{OH}$ gelatin \\
\hline $\mathrm{I}^{\circ}-1-5 \mathrm{mg} / \mathrm{ml}$ & $\mathrm{II}^{\circ}-1-5 \mathrm{mg} / \mathrm{ml}$ & $\mathrm{III}^{\circ}-1-5 \mathrm{mg} / \mathrm{ml}$ & $\mathrm{IV}^{\circ}-1-5 \mathrm{mg} / \mathrm{ml}$ & $\mathrm{V}^{\circ}-1-5 \mathrm{mg} / \mathrm{ml}$ & $\mathrm{VI}^{\circ}-1-5 \mathrm{mg} / \mathrm{ml}$ \\
\hline $\mathrm{I}^{\circ}-2-1 \mathrm{mg} / \mathrm{ml}$ & $\mathrm{II}^{\circ}-2-1 \mathrm{mg} / \mathrm{ml}$ & III $^{\circ}-2-1 \mathrm{mg} / \mathrm{ml}$ & $\mathrm{IV}^{\circ}-2-1 \mathrm{mg} / \mathrm{ml}$ & $\mathrm{V}^{\circ}-2-1 \mathrm{mg} / \mathrm{ml}$ & $\mathrm{VI}^{\circ}-2-1 \mathrm{mg} / \mathrm{ml}$ \\
\hline $\mathrm{I}^{\circ}-3-0.5 \mathrm{mg} / \mathrm{ml}$ & $\mathrm{II}^{\circ}-3-0.5 \mathrm{mg} / \mathrm{ml}$ & III $^{\circ}-3-0.5 \mathrm{mg} / \mathrm{ml}$ & $\mathrm{IV}^{\circ}-3-0.5 \mathrm{mg} / \mathrm{ml}$ & $\mathrm{V}^{\circ}-3-0.5 \mathrm{mg} / \mathrm{ml}$ & $\mathrm{VI}^{\circ}-3-0.5 \mathrm{mg} / \mathrm{ml}$ \\
\hline $\mathrm{I}^{\circ}-4-0.1 \mathrm{mg} / \mathrm{ml}$ & $\mathrm{II}^{\circ}-4-0.1 \mathrm{mg} / \mathrm{ml}$ & $\mathrm{III}^{\circ}-4-0.1 \mathrm{mg} / \mathrm{ml}$ & $\mathrm{IV}^{\circ}-4-0.1 \mathrm{mg} / \mathrm{ml}$ & $\mathrm{V}^{\circ}-4-0.1 \mathrm{mg} / \mathrm{ml}$ & $\mathrm{VI}^{\circ}-4-0.1 \mathrm{mg} / \mathrm{ml}$ \\
\hline
\end{tabular}

TABle 4: The synthesis ways of the Ag-Cu BNPs.

\begin{tabular}{lccc}
\hline Sample no. & Samples & Stabilizer & Medium reaction \\
\hline 1 & $\mathrm{Ag}-\mathrm{Cu}$ & Gelatin & Neutral \\
2 & $\mathrm{Ag}-\mathrm{Cu}$ & Gelatin & $\mathrm{NaOH}$ \\
3 & $\mathrm{Ag}-\mathrm{Cu}$ & Gelatin & $\mathrm{NH}_{4} \mathrm{OH}$ \\
4 & $\mathrm{Ag}-\mathrm{Cu}$ & - & $\mathrm{NH}_{4} \mathrm{OH}$ \\
5 & $\mathrm{Ag}-\mathrm{Cu}$ & - & $\mathrm{NaOH}$ \\
6 & $\mathrm{Ag}-\mathrm{Cu}$ & - & Neutral \\
7 & $\mathrm{Ag}-\mathrm{Cu}$ & - & Acidic \\
\hline
\end{tabular}

After the specified time, the diameters of the growth inhibition zones were measured. Highly active NPs were considered to be those samples that exhibited more extensive zones of inhibition. Chemical colloidal Ag Xerox, copper sulphate preparations, and a natural preparation based on Streptomyces bacteria were used to compare the biological activities of the tested BNPs.

\subsection{Tests Used to Determine the Effects of the MNPs and BNPs on Wheat and Corn Seeds}

2.5.1. Seeds. The wheat (Tríticum) variety "Intensive" seeds and corn (Zea) "Pioneer" grains from the National Seed Gene Bank Kyrgyzstan were used.

2.5.2. Seed Germination and Exposure. To prevent seedborne microorganisms, the seeds were sterilized with $5 \%$ sodium hypochlorite solution for $5 \mathrm{~min}$ and washed three times with sterilized distilled water. Then, seeds were soaked in NP solutions and a suspension of a biological product for $2 \mathrm{~h}$ for comparison.

Each NP sample was tested on 30 seeds. The experiment included three replicates. Germination was recorded daily for 12 days, at which time the germination percentage was calculated. After 8-12 days (because of different types of seed germinate at different times), depending on the type of grain, treatment was halted and seedling root and shoot length were measured. Distilled water was used as a control. To compare the phytoregulatory effect of the NP samples, Streptomyces violaceoruber and Streptomyces diastochromogenes bioproducts were used as biostimulators (Table 6).

2.5.3. Seed Germination Measurement. According to the International Rules for Testing Seeds, the final percentage 
TABle 5: The Ag-Cu BNPs tested for antibacterial activity.

\begin{tabular}{|c|c|c|c|}
\hline \multirow{2}{*}{ Sample no } & \multirow{2}{*}{ Ag-Cu BNP } & \multicolumn{2}{|c|}{ Ag-Cu BNP concentration } \\
\hline & & $\mathrm{AgNO}_{3}$ concentration & $\mathrm{CuSO}_{4}$ concentration \\
\hline 1 & $\mathrm{Ag}-\mathrm{Cu}$ (neutral media) & $0.05 \mathrm{~mol}, 20 \mathrm{ml}$, and $\mathrm{pH}=7.0$ & $0.05 \mathrm{~mol}, 20 \mathrm{ml}$, and $\mathrm{pH}=7.0$ \\
\hline 2 & $\mathrm{Ag}-\mathrm{Cu}$ (ammonia media) & $0.05 \mathrm{~mol}, 20 \mathrm{ml}$, and $\mathrm{pH}=11.0$ & $0.05 \mathrm{~mol}, 20 \mathrm{ml}$, and $\mathrm{pH}=11.0$ \\
\hline 3 & Ag-Cu (alkaline media) & $0.05 \mathrm{~mol}, 20 \mathrm{ml}$, and $\mathrm{pH}=11.0$ & $0.05 \mathrm{~mol}, 20 \mathrm{ml}$, and $\mathrm{pH}=11.0$ \\
\hline 4 & $\mathrm{Ag}-\mathrm{Cu}$ with gelatin (neutral media) & $0.05 \mathrm{~mol}, 20 \mathrm{ml}$, and $\mathrm{pH}=7.0$ & $0.05 \mathrm{~mol}, 20 \mathrm{ml}$, and $\mathrm{pH}=7.0$ \\
\hline 5 & Ag-Cu with gelatin (ammonia media) & $0.05 \mathrm{~mol}, 20 \mathrm{ml}$, and $\mathrm{pH}=11.0$ & $0.05 \mathrm{~mol}, 20 \mathrm{ml}$, and $\mathrm{pH}=11.0$ \\
\hline 6 & Ag-Cu with gelatin (alkaline media) & $0.05 \mathrm{~mol}, 20 \mathrm{ml}$, and $\mathrm{pH}=11.0$ & $0.05 \mathrm{~mol}, 20 \mathrm{ml}$, and $\mathrm{pH}=11.0$ \\
\hline
\end{tabular}

TABLE 6: The NP and control concentrations and the seed exposure times.

\begin{tabular}{|c|c|c|c|c|}
\hline Test variant & Composition & NP or bioproduct concentration & Seed exposure time & Seed types \\
\hline MNP & $\mathrm{Ag}$ & $1 \mathrm{mg} / \mathrm{l}$ & $2 \mathrm{~h}$ & Wheat and corn \\
\hline MNP & $\mathrm{Cu}$ & $1 \mathrm{mg} / \mathrm{l}$ & $2 \mathrm{~h}$ & Wheat and corn \\
\hline BNP & $\mathrm{Ag}-\mathrm{Cu}$ in alkaline medium & $1 \mathrm{mg} / \mathrm{l}$ & $2 \mathrm{~h}$ & Wheat and corn \\
\hline BNP & Ag-Cu in neutral medium & $1 \mathrm{mg} / \mathrm{l}$ & $2 \mathrm{~h}$ & Wheat and corn \\
\hline BNP & $\mathrm{Ag}-\mathrm{Cu}$ in ammonium medium & $1 \mathrm{mg} / \mathrm{l}$ & $2 \mathrm{~h}$ & Wheat and corn \\
\hline Control & Distilled water & & $2 \mathrm{~h}$ & Wheat and corn \\
\hline Biostimulator & Streptomyces violaceoruber & $10^{3}$ spores $/ \mathrm{ml}$ & $2 \mathrm{~h}$ & Wheat and corn \\
\hline Biostimulator & Streptomyces diastochromogenes & $10^{3}$ spores $/ \mathrm{ml}$ & $2 \mathrm{~h}$ & Wheat and corn \\
\hline
\end{tabular}

TABle 7: The inhibition of bacterial pathogen's growth under effects of Ag and Cu NPs in $1.0 \mathrm{mg} / \mathrm{l}$ doze $(n=3)$.

\begin{tabular}{ccccccc}
\hline No. & Samples & Stabilizer & The reaction medium & Pseudomonas syringae $\begin{array}{c}\text { Causative agents of plant diseases } \\
\text { Erwinia amylovora } \\
\text { Lysis zone, mm }(n=3)\end{array}$ \\
\hline 1 & $\mathrm{Ag}-\mathrm{Cu}$ & Gelatin & Neutral & $6.1 \pm 0.25$ & $6.0 \pm 0.10$ & $7.1 \pm 0.89$ \\
2 & $\mathrm{Ag}-\mathrm{Cu}$ & Gelatin & $\mathrm{NaOH}$ & $8.0 \pm 0.02$ & $7.0 \pm 0.14$ & $7.1 \pm 0.92$ \\
3 & $\mathrm{Ag}-\mathrm{Cu}$ & Gelatin & $\mathrm{NH}_{4} \mathrm{OH}$ & $7.0 \pm 0.23$ & $7.0 \pm 0.13$ & $7.2 \pm 0.87$ \\
4 & $\mathrm{Ag}$ & Gelatin & $\mathrm{NaOH}$ & $2.0 \pm 0.25$ & $3.0 \pm 0.51$ & $5.0 \pm 0.43$ \\
5 & $\mathrm{Cu}$ & Gelatin & $\mathrm{NaOH}$ & $4.0 \pm 0.10$ & $4.0 \pm 0.97$ & $4.7 \pm 0.51$ \\
\hline
\end{tabular}

of germination and measurements of grown organs were carried out [32]. The following equations were used to calculate seed germination. Germination percentage $(\mathrm{GP} \%)=($ $\mathrm{Gf} / n) \times 100$ where Gf is the total number of germinated seeds at the end of experiment and $n$ is the total number of seed used in the test. Mean germination time (MGT) $=$ $\Sigma N i D i / n$ where $N i$ is the number of germinated seeds till $i$ th day and $D i$ is the number of days from start of experiment till $i$ th counting and $n$ is total germinated seeds. Germination rate $(\mathrm{GR})=\Sigma N i / \Sigma T i N i$ where $N i$ is the number of newly germinated seeds at the time of $T i=(a / 1)+(b-a / 2$ )$+(c-b / 3)+\cdots+(n-n-1 / N)$.

2.5.4. Statistical Analysis. The experiment was replicated thrice. Data were stated as the means of three replications. Statistical analyses were performed using SAS JMP Statistical Package version 13.0. The means of metallic nanoparticles, doses, and interactions were considered significant if $P<$ 0.05 .

\section{Results and Discussion}

3.1. The Morphology and Dimensions of Ag and Cu NPs Synthesized in Various Media. Diffraction patterns of the products of the combined reduction of silver and copper ions in the presence of gelatin are shown in Figure 1. Analysis of the diffraction patterns shows that the outcomes of the three samples consist of two phases: metallic silver and copper.

The average lattice parameter of silver and copper obtained in all three samples is $0.40 \mathrm{~nm}$ and $0.35 \mathrm{~nm}$, respectively. Calculations show that the value of the crystal lattice parameter of metals corresponds to that for massive metals (JCPDS no. 04-0783 and no. 04-0836). This value indicates that the reduction of ions in stabilizers leads to the formation of silver and copper nanocomposites [33-35].

Diffraction patterns of the products of the combined reduction of silver and copper ions in the absence of gelatin are shown in Figure 2. Analysis of diffraction patterns of the 


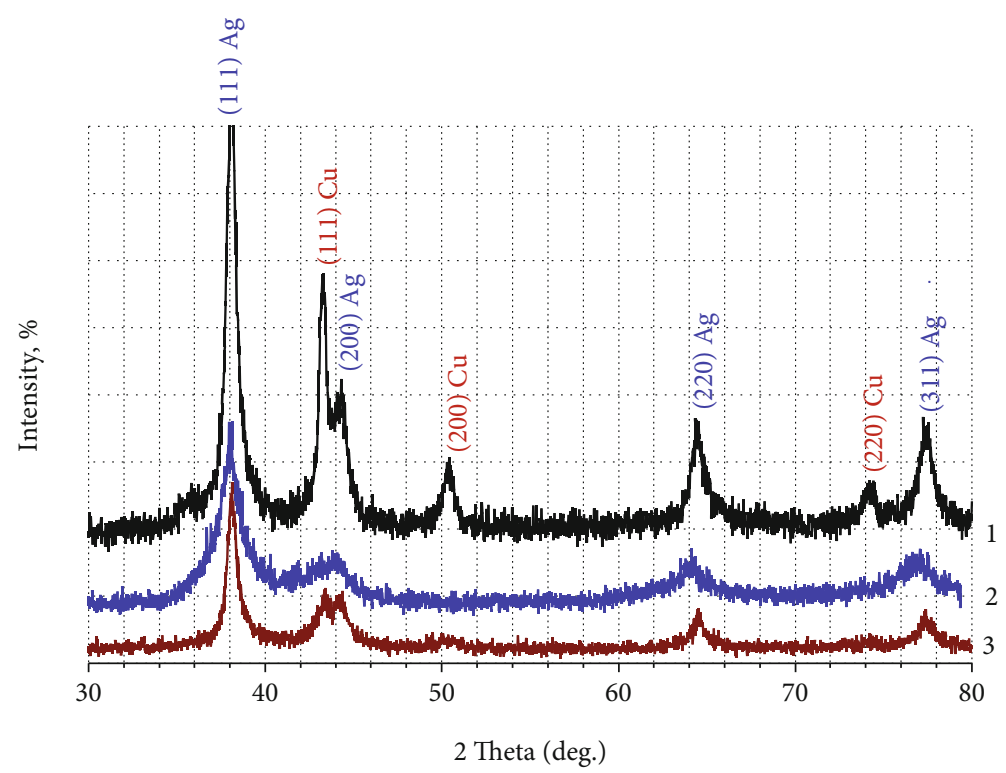

Figure 1: Diffraction patterns of the products of the combined reduction of silver and copper ions in the presence of gelatin in neutral (1), alkaline (2), and ammonia (3) media.

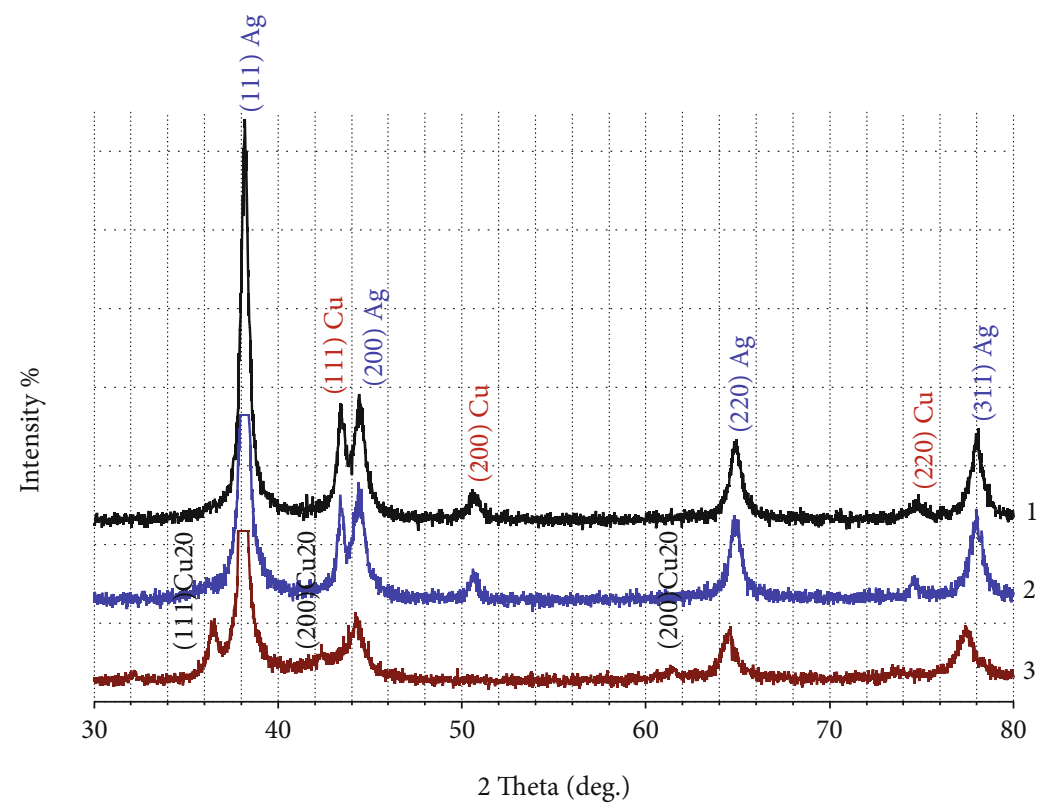

FIGURE 2: Diffraction patterns of the products of the combined reduction of silver and copper ions in ammonia (1), alkaline (2), and neutral (3) media.

joint reduction of silver and copper ions without a stabilizer indicates that the products obtained in alkaline and ammonia media consist of two phases: metallic silver and copper. The average lattice parameter is $0.4095 \mathrm{~nm}$ for silver and $0.362 \mathrm{~nm}$ for copper. The product synthesized in a neutral medium except the metallic phases also contains a third phase-copper oxide (I) $[34,36]$.

The morphology and dimensions of silver and copper nanocomposites were determined by using scanning electron microscopy. To determine the size of silver and copper nanoparticles, the histograms of the corresponding nanopowders were compiled from the analysis of their micrographs.
As shown in the micrograph (Figures 3-5), regardless of the presence of a stabilizer in various media, the particles of all six samples had a spherical shape. NPs obtained in the presence of gelatin in a neutral medium (Figure 3(a)) ranged from 10 to $170 \mathrm{~nm}$, and particles with dimensions of 60 $100 \mathrm{~nm}$ and $150-170 \mathrm{~nm}$ were predominant. In the presence of gelatin in an alkaline medium, the formed $\mathrm{Ag}$ and $\mathrm{Cu}$ NPs ranged from 20 to $120 \mathrm{~nm}$ and most were $20-40 \mathrm{~nm}$ in size (Figure 3(b)). Particles of a nanocomposite of $\mathrm{Ag}$ and $\mathrm{Cu}$ (Figure 4(a)) obtained in an ammonia medium in the presence of a stabilizer were $10-170 \mathrm{~nm}$; aggregates $40-60 \mathrm{~nm}$ were predominant. The products obtained in ammonia in 


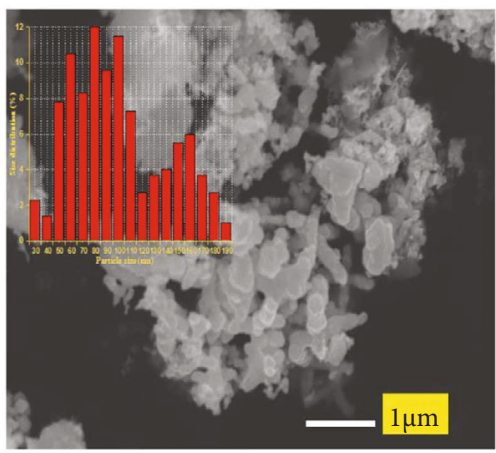

(a)

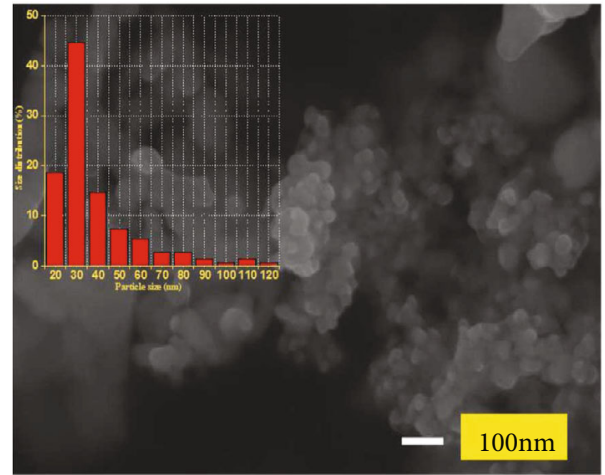

(b)

Figure 3: Micrograph and histogram of silver and copper nanocomposite particles synthesized in the presence of gelatin in a neutral medium (a) and the presence of gelatin in an alkaline medium (b).

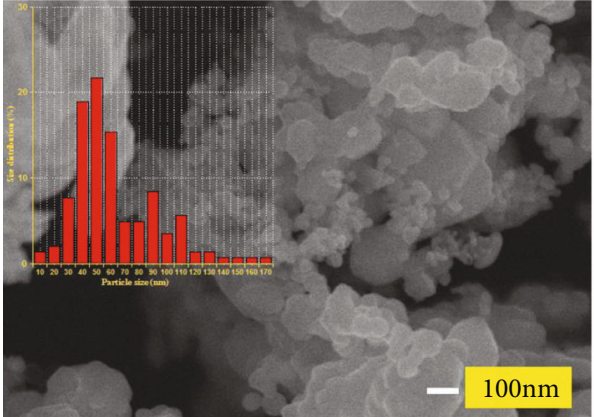

(a)

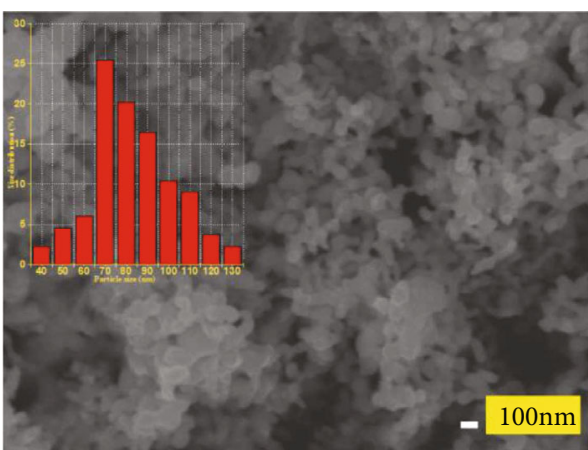

(b)

Figure 4: Micrograph and histogram of silver and copper nanocomposite particles synthesized in the presence of gelatin in ammonia (a) and the absence of gelatin in ammonia medium (b).

the absence of a stabilizer were spherical. Analysis of the particle histogram (Figure 4(b)) by size showed the predominance of particles that were $70-90 \mathrm{~nm}$. In addition, the sample contained particles with dimensions of 40, 50, and 60 and from 100 to $130 \mathrm{~nm}$.

The particle size in the nanopowder synthesized in an alkaline medium (Figure 5(a)) was, on average, $40-70 \mathrm{~nm}$. The NPs obtained in a neutral medium were $40-60 \mathrm{~nm}$ in length (Figure 5(b)).

These findings show that the inclusion of gelatin makes it possible to obtain stable $\mathrm{Ag}-\mathrm{Cu}$ nanocomposites with smaller sizes and a narrower size distribution than the absence of a stabilizer. The minor aggregates of NPs formed in an alkaline medium.

\subsection{Effects of NPs on Plant Pathogens}

3.2.1. Brief Characteristics of the Pathogenic Bacteria. E. amylovora is a Gram-negative bacteria consisting of rods that are 1.0-3.0 microns in length and 0.5-1.0 microns in diameter. They are mobile, peritrichous flagellated, heterotrophic, facultative anaerobes. They are associated with plants as epiphytes, saprotrophs, and phytopathogens. E. amylovora is a devastating bacterial plant pathogen of the Rosaceae family, causing the disease fire blight, spreading rapidly across many countries and causing substantial economic damage. The bacterial cultures used in this work were isolated from diseased organs of apple and pear trees grown in orchards and forestry farms in northern and southern Kyrgyzstan. They were genetically identified, and their degree of pathogenicity was determined $[37,38]$.

The phylogenetic tree produced from the I6S gene sequences of the Erwinia amylovora KTMU 5-6 strain used in this study is presented in Figure 6.

Ps. syringae pv. syringae is a rod-shaped, Gram-negative bacterium with polar flagella. It can cause disease in more than 180 plant species, including annual and perennial plants, fruit trees, ornamentals, and vegetables [39]. In Kyrgyzstan, essential fruit crops, such as apricots, plums, cherries, and other stone fruits, suffer from bacterial canker caused by this bacterium [40] (Figure 7).

The phylogenetic tree produced from the I6S gene sequences of Pseudomonas syringae KTMU strain used in this study is presented in Figure 8.

$P$. carotovorum was named after the phytopathologist Erwin Frink Smith (1854-1927), the first to study this pathogen. This bacterium lives in colonies and as solitary rods, 1-3 microns in size, and forms short chains. A heterotrophic facultative aerobe is the causative agent of mild rot in potatoes (potato blight) and other vegetables (Figure 9). The optimum temperature range for this pathogen is $18-25^{\circ} \mathrm{C}$, and it thrives in moist soil. The pathogen damages the 


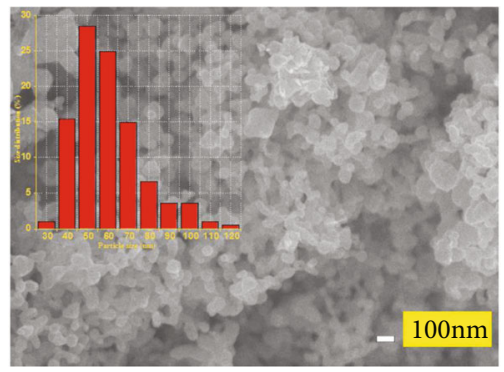

(a)

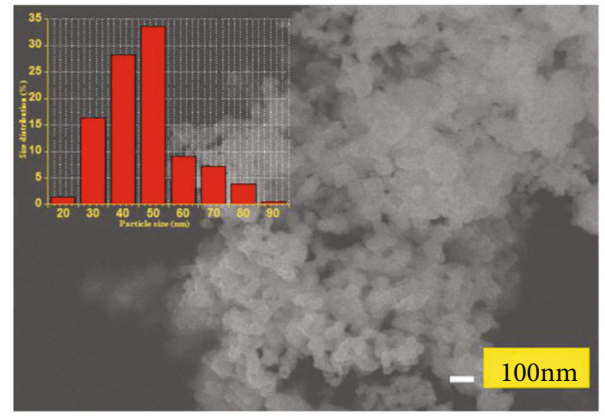

(b)

FIGURE 5: Micrograph and histogram of silver and copper nanocomposite particles synthesized in an alkaline medium (a) and in the neutral medium (b).

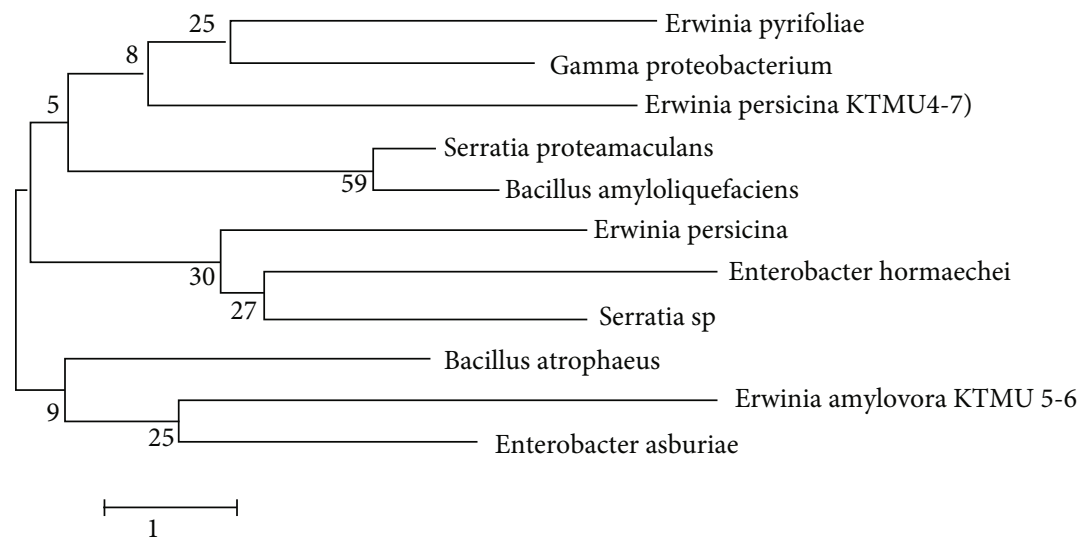

FIGURE 6: The phylogenetic tree produced from the I6S gene sequences showing the phylogenetic relationships of Erwinia amylovora KTMU 5-6 strain with Gram-negative and Gram-positive bacteria using the neighbor-joining method. Relevant bootstrap values (expressed as a percentage of 1000 replicates) are shown at branch points, and the bar (1.0) changes per sequence position.

aboveground plant parts and the underground organs and joints. It reduces yield by $50-75 \%$. The phylogenetic tree produced from the I6S gene sequences of Pectobacterium carotovorum strain used in this study is presented in Figure 10.

3.2.2. In Vitro Biological Activity of Ag MNPs against Bacterial Pathogens. Of all the tested concentrations, only high-concentration Ag MNP solutions showed antibacterial

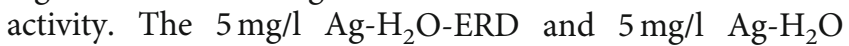
gelatin-ERD MNPs showed higher activity against the bacterial canker pathogen ( $P$. syringae pv. syringae) than the other pathogens. The lysis zone of bacterial colony growth reached $7.0 \pm 1.01 \mathrm{~mm}(P>0.05)$. However, these solutions in any concentration had no antibacterial effect on $P$. carotovorum and E. amylovora. While the high concentration $(5 \mathrm{mg} / \mathrm{l})$ of Ag- $\mathrm{H}_{2} \mathrm{O}$ and $\mathrm{Ag}-\mathrm{NH}_{4} \mathrm{OH}$ solutions also positively affected the bacterial canker pathogen ( $P$ s. syringae pv. syringae) and the vegetable bacteriosis pathogen ( $P$. carotovorum) (Figures 11-13).

3.2.3. In Vitro Biological Activity of $\mathrm{Cu}$ MNPs against Bacterial Pathogens. Different concentrations of $\mathrm{Cu}$ MNPs synthesized by various methods were tested for their antibacterial activity against plant pathogens. The antibacterial activities of the Cu NPs were also compared to those of the
Ag NPs. Cu- $\mathrm{H}_{2} \mathrm{O}, \mathrm{Cu}-\mathrm{H}_{2} \mathrm{O}$-gelatin, and $\mathrm{Cu}-\mathrm{NH}_{4} \mathrm{OH}$-gelatin NPs at $1-5 \mathrm{mg} / \mathrm{l}$ showed insignificant activity against $P$. carotovorum. At all three tested concentrations, the lysis zone was $0.3 \pm 0.01 \mathrm{~mm}$. Lower concentrations did not show any effect at all.

$\mathrm{Cu}-\mathrm{H}_{2} \mathrm{O}-\mathrm{ERD}, \mathrm{Cu}-\mathrm{H}_{2} \mathrm{O}$-gelatin, and $\mathrm{Cu}-\mathrm{NH}_{4} \mathrm{OH}$-gelatin at $1-5 \mathrm{mg} / \mathrm{l}$ showed high activity against Ps. syringae. Significantly, at $5 \mathrm{mg} / \mathrm{l}$, all the samples had high activity. The lysis zone reached $10.0 \pm 0.95 \mathrm{~mm}$.

At 5.0, 1.0, and $0.5 \mathrm{mg} / \mathrm{l}, \mathrm{Cu}-\mathrm{NH}_{4} \mathrm{OH}, \mathrm{Cu}-\mathrm{NH}_{4} \mathrm{OH}$-gelatin, and $\mathrm{Cu}-\mathrm{H}_{2} \mathrm{O}$-gelatin each exhibited good activity against E. amylovora. $\mathrm{Cu}-\mathrm{H}_{2} \mathrm{O}$-gelatin-ERD at $5 \mathrm{mg} / \mathrm{l}$ resulted in a lysis zone of $12.0 \pm 0.95 \mathrm{~mm}$ (Figures 14-17).

The use of the chemicals (Xerox colloidal Ag preparation and copper sulphate) resulted in no lysis zone. Thick masses of bacterial colonies were observed, despite the high concentrations (5 mg/l) used (Figure 18).

Furthermore, $\mathrm{Cu}$ NPs were tested under field conditions. Apricot trees were treated with this $\mathrm{Cu}$ NPs. The preliminary results were positive, with reductions in pathogen populations observed. However, these studies should be continued and repeated (see Figure S3 in the supplementary material).

3.2.4. In Vitro Biological Activity of $\mathrm{Ag}-\mathrm{Cu}$ BNPs against Bacterial Pathogens. The BNPs prepared in neutral, 


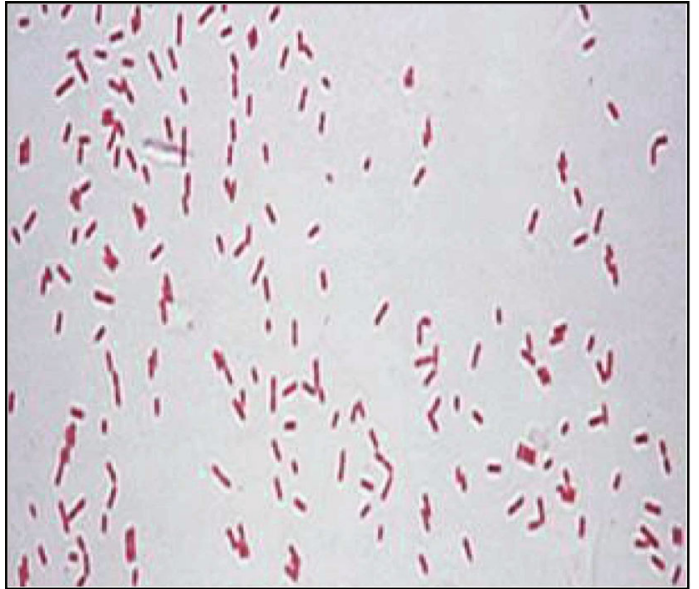

(a)

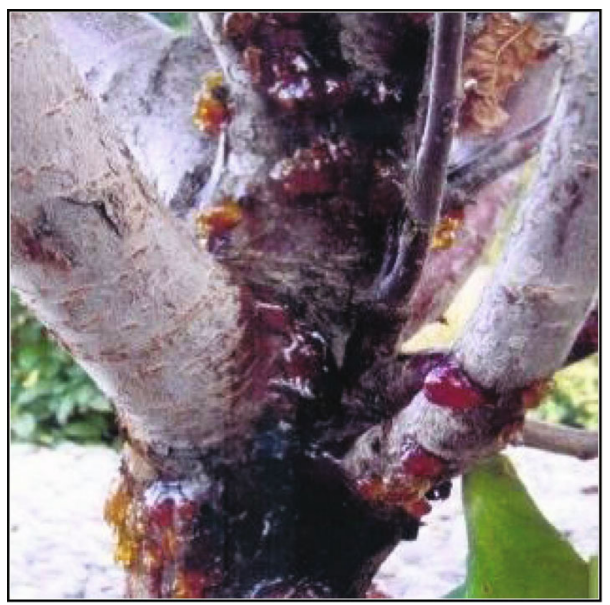

(c)

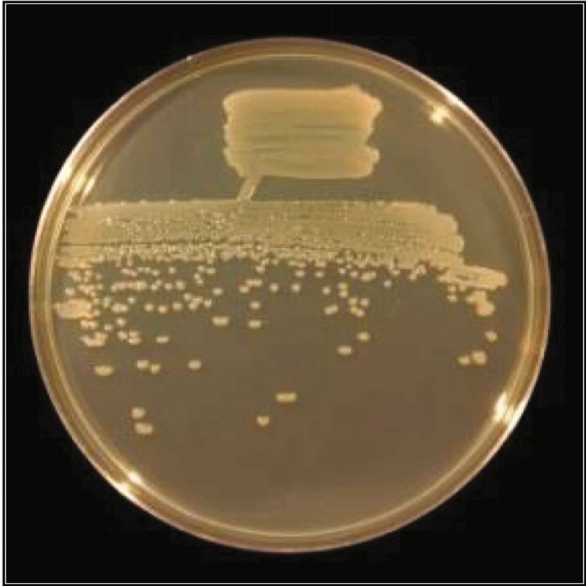

(b)

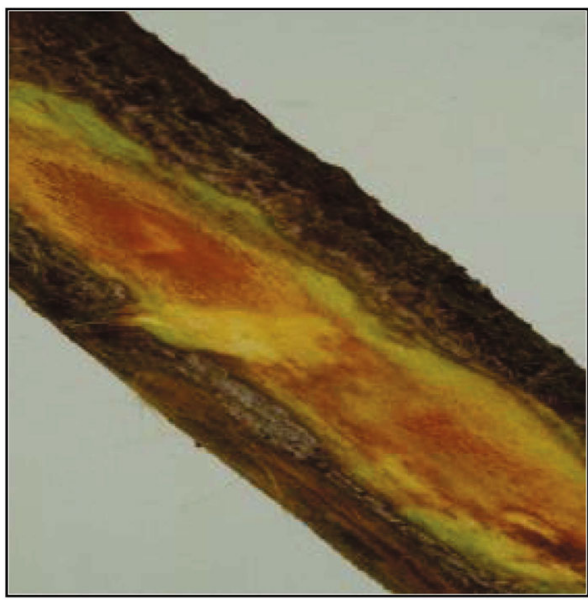

(d)

Figure 7: (a) Microscopic view of Pseudomonas syringae cells; (b) colonial growth on the agar medium; (c) adverse effects on the plants; (d) symptoms on an infected branch.

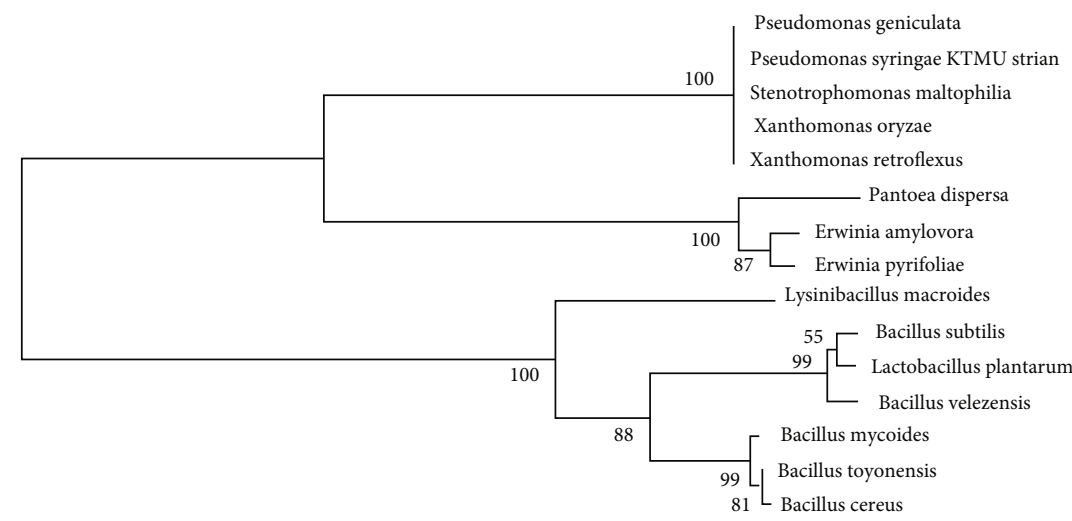

0.02

FIgURe 8: Phylogenetic tree produced from the I6S gene sequences showing the phylogenetic relationships of Pseudomonas syringae KTMU strain with Gram-negative and Gram-positive bacteria using the neighbor-joining method. Relevant bootstrap values (expressed as a percentage of 1000 replicates) are shown at branch points, and bar (0.02) changes per sequence position. 


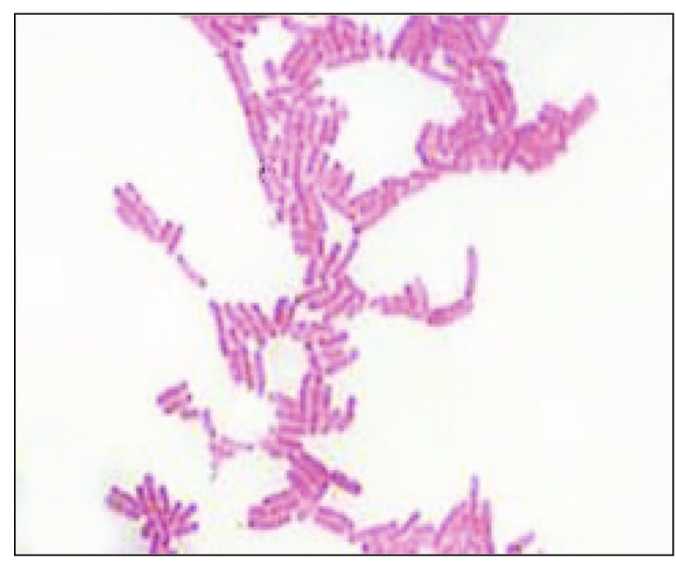

(a)

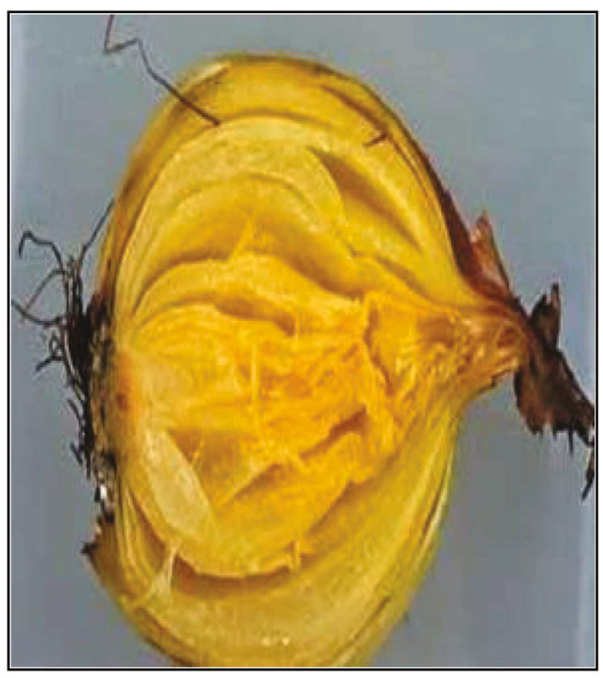

(c)

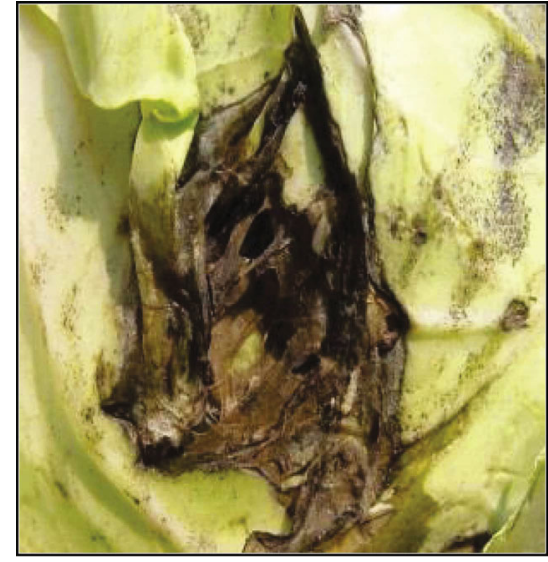

(b)

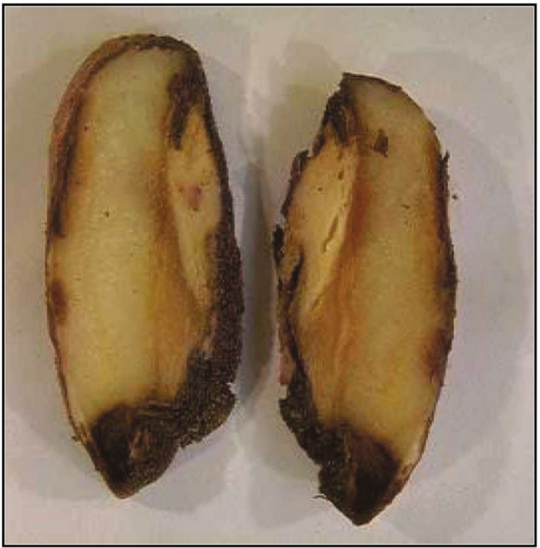

(d)

Figure 9: (a) Microscopic view of Pectobacterium carotovorum bacterium cells; (b) symptoms of cabbage bacteriosis; (c) symptoms of onion bacteriosis; (d) symptoms of wet potato rot.

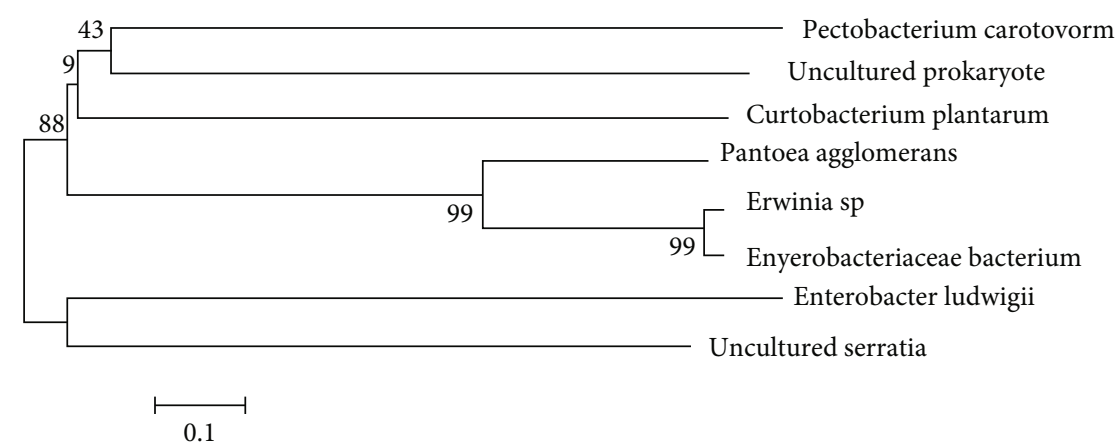

FIGURE 10: Phylogenetic tree produced from the I6 S gene sequences showing the phylogenetic relationships of Pectobacterium carotovorum strain with Gram-negative and Gram-positive bacteria using the neighbor-joining method. Relevant bootstrap values (expressed as a percentage of 1000 replicates) are shown at branch points, and the bar (0.1) changes per sequence position. 


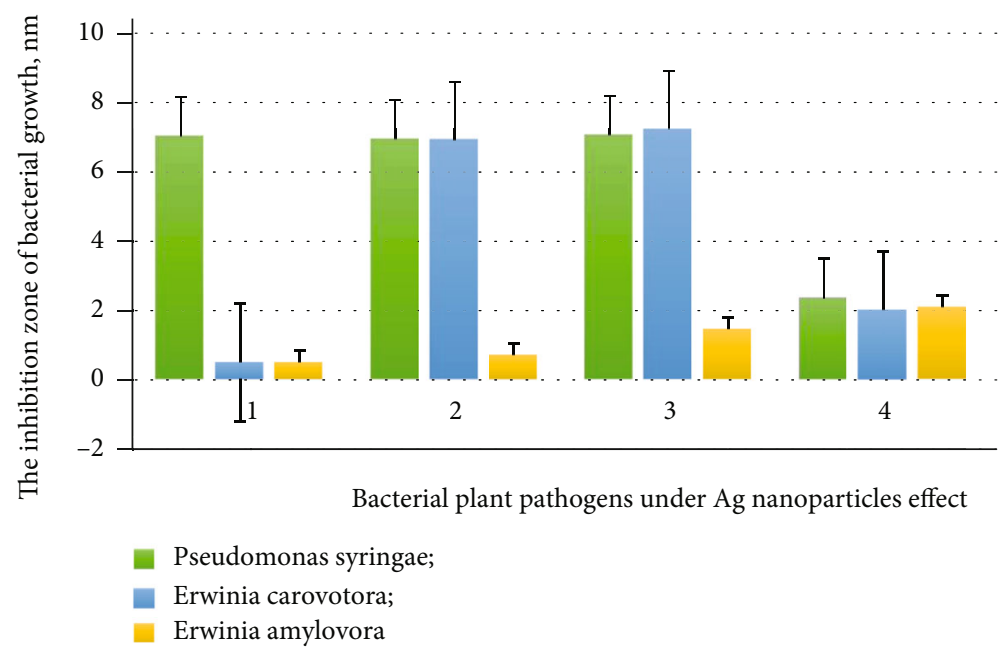

Figure 11: Effects of Ag NPs on bacterial diseases of various plants: $1-5 \mathrm{mg} / \mathrm{l}$ of $\mathrm{AgH}_{2} \mathrm{O}$ EID; $2-5 \mathrm{mg} / \mathrm{l}$ of Ag- $\mathrm{H}_{2} \mathrm{O}$ gelatin-ERD; 3-5 mg/l of $\mathrm{Ag}-\mathrm{H}_{2} \mathrm{O} ; 4-5 \mathrm{mg} / \mathrm{l}$ of $\mathrm{AgNH}_{4} \mathrm{OH}$.

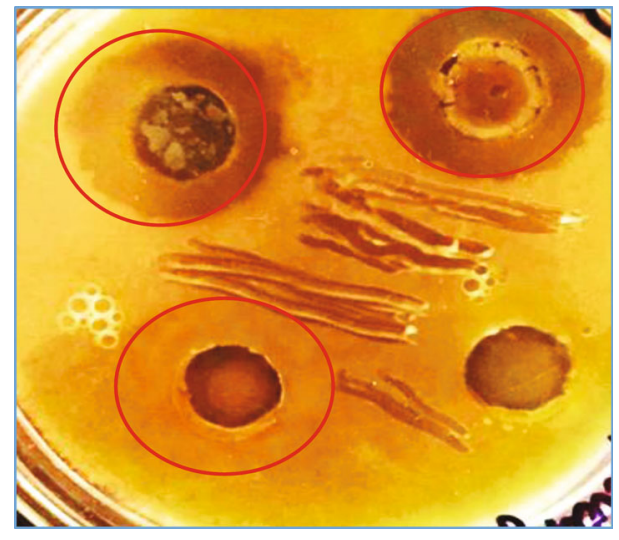

(a)

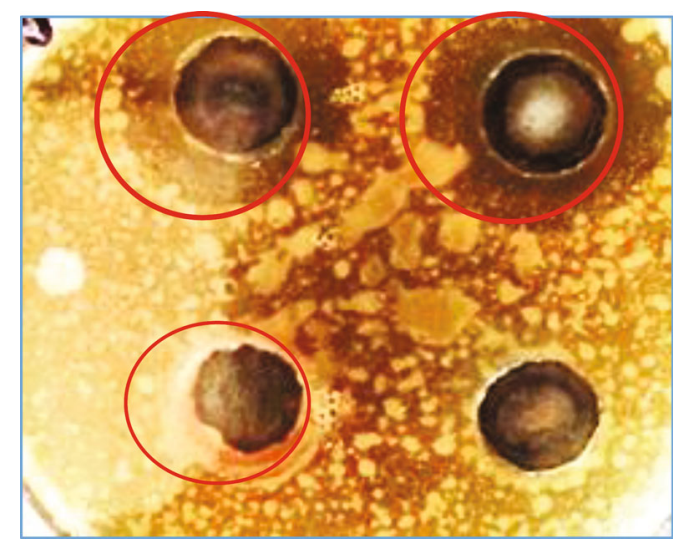

(b)

FIGURE 12: The pictures of lysis zones of bacterial growth around the well on agar medium with Ag NPs: (a) an activity of Ag-H2O-EID and $\mathrm{Ag}-\mathrm{H} 2 \mathrm{O}$ gelatin-ERD samples against Pseudomonas syringae (bacterial canker of plums); (b) Ag-H2O-EID and Ag-H2O gelatin-ERD sample activity against Pectobacterium carotovorum (bacteriosis of vegetables).

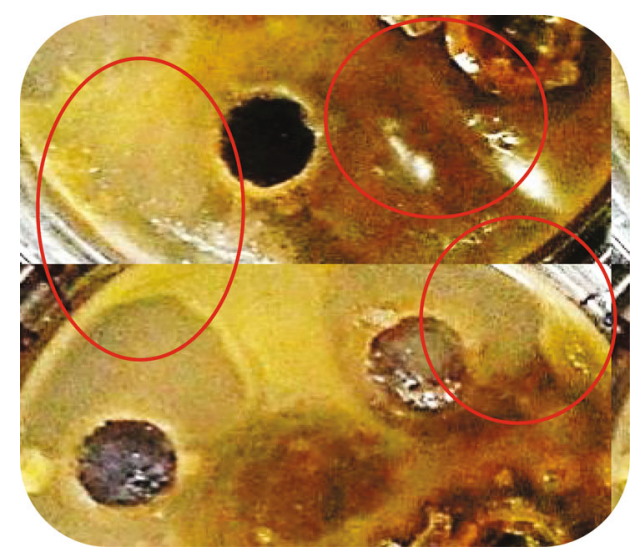

(a)

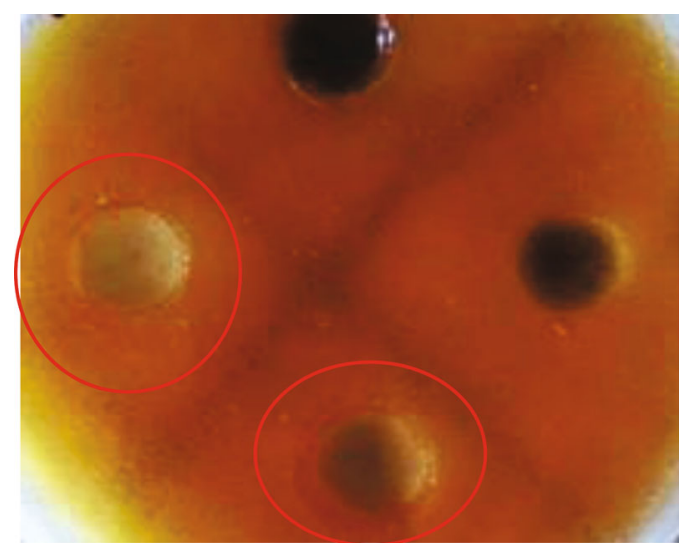

(b)

FIgURE 13: The pictures of lysis zones of bacterial growth around the well on agar medium with Ag NPs: (a) an activity of Ag- $\mathrm{H}_{2} \mathrm{O}-\mathrm{EID}$, Ag$\mathrm{H}_{2} \mathrm{O}$ gelatin-ERD, and $\mathrm{Ag}-\mathrm{H}_{2} \mathrm{O}$ against Ps. syringae (bacterial canker of apples); (b) activity of $\mathrm{Ag}-\mathrm{H}_{2} \mathrm{O}$ and $\mathrm{AgNH} \mathrm{H}_{4} \mathrm{OH}$ samples against $E$. amylovora (bacterial blight of pears). 


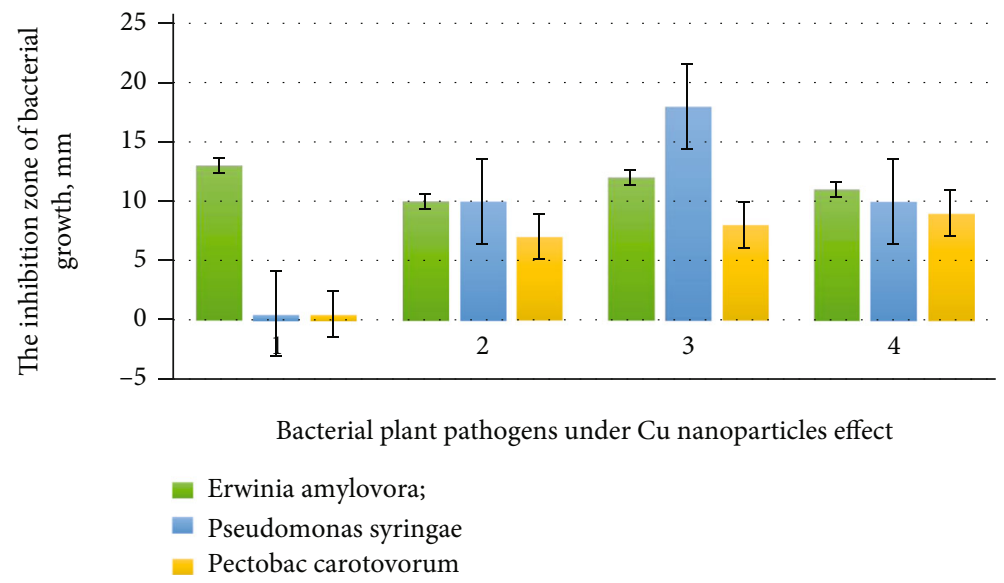

FIgure 14: Effect of $\mathrm{Cu}$ NPs on bacterial diseases of various plants: 1-1-5 mg/l of Cu- $\mathrm{H}_{2} \mathrm{O}-\mathrm{EID} ; 2-1-5 \mathrm{mg} / \mathrm{l}$ of Cu- $\mathrm{H}_{2} \mathrm{O}$ gelatin-ERD; $3-1-$ $5 \mathrm{mg} / \mathrm{l}$ of $\mathrm{Cu}-\mathrm{H}_{2} \mathrm{O} ; 4-1-5 \mathrm{mg} / \mathrm{l}$ of $\mathrm{Cu}-\mathrm{H}_{2} \mathrm{O}$-gelatin.

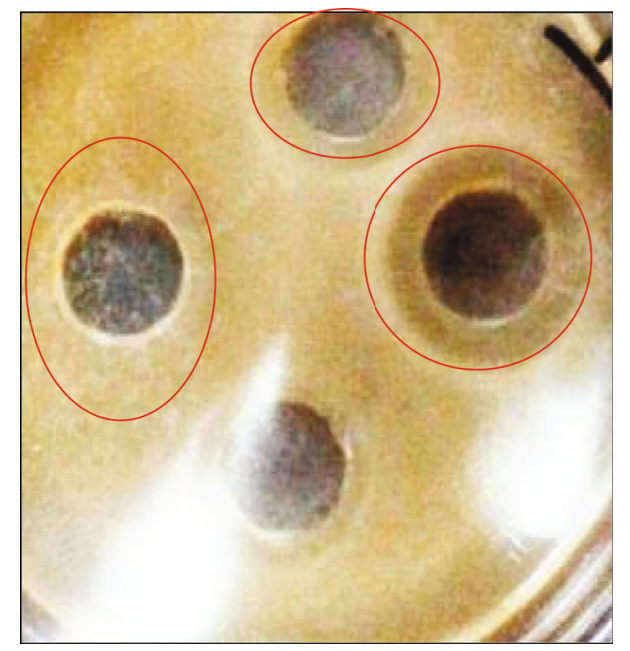

(a)

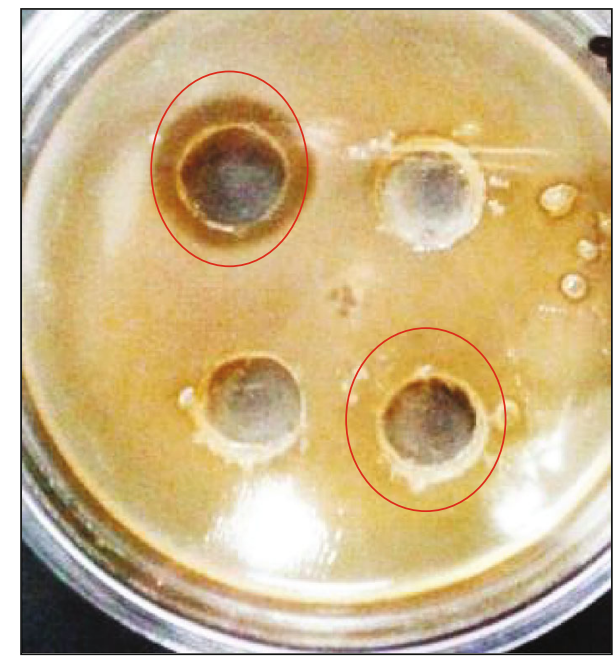

(b)

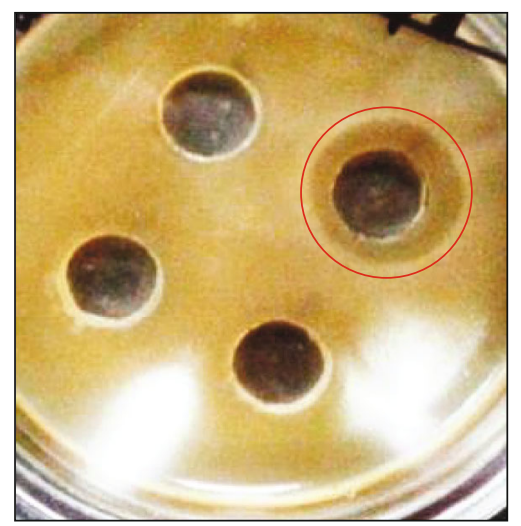

(c)

FIgUre 15: The pictures of lysis zones of $P$. carotovorum growth around the well on agar medium with $\mathrm{Cu} N P$ s: $(\mathrm{a}) \mathrm{Cu}-\mathrm{H}_{2} \mathrm{O}-\mathrm{EID}$; (b) $\mathrm{Cu}-$ $\mathrm{H}_{2} \mathrm{O}$ gelatin-ERD; (c) $\mathrm{Cu}-\mathrm{Cu}-\mathrm{H}_{2} \mathrm{O}$-gelatin. 


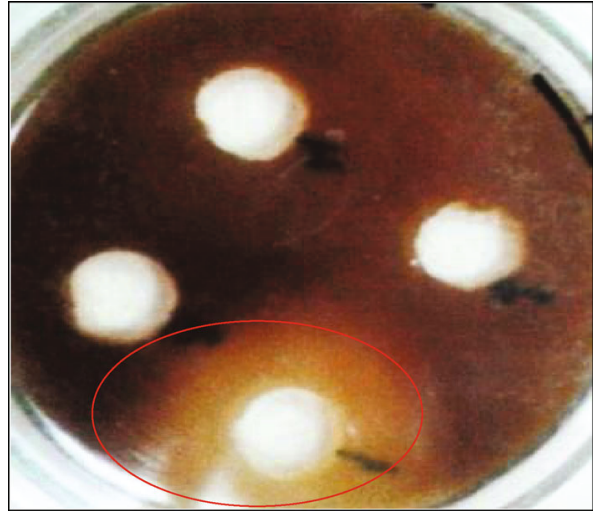

(a)

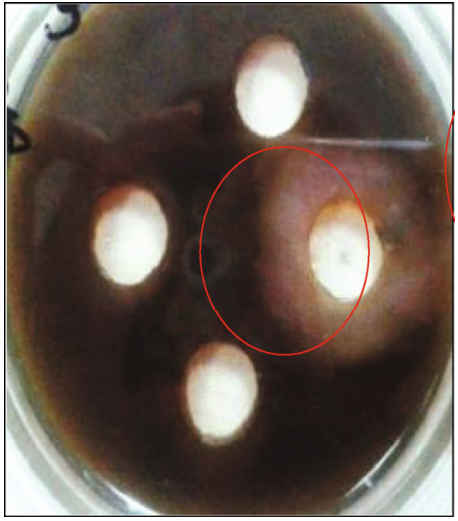

(b)

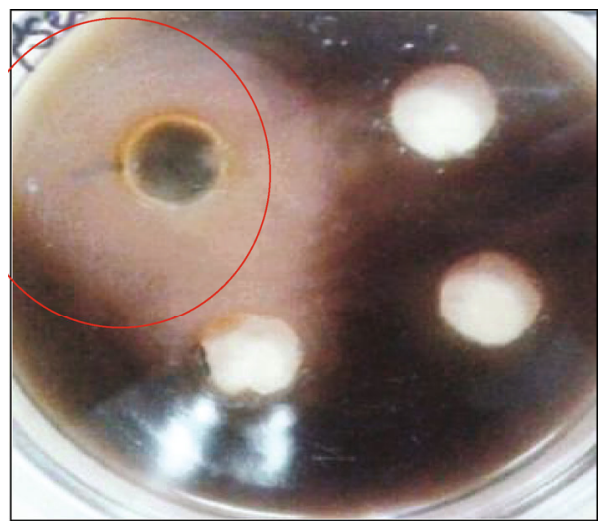

(c)

Figure 16: The pictures of lysis zones of Ps. syringae growth around the well on agar medium with $\mathrm{Cu}$ NPs: (a) $\mathrm{Cu}-\mathrm{H}_{2} \mathrm{O}-\mathrm{EID}$; (b) $\mathrm{Cu}-\mathrm{H}_{2} \mathrm{O}$ gelatin-ERD; (c) $\mathrm{Cu}-\mathrm{Cu}-\mathrm{H}_{2} \mathrm{O}$-gelatin.

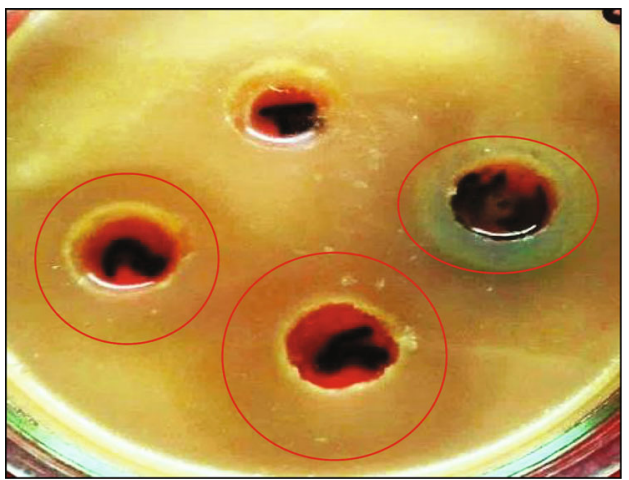

(a)

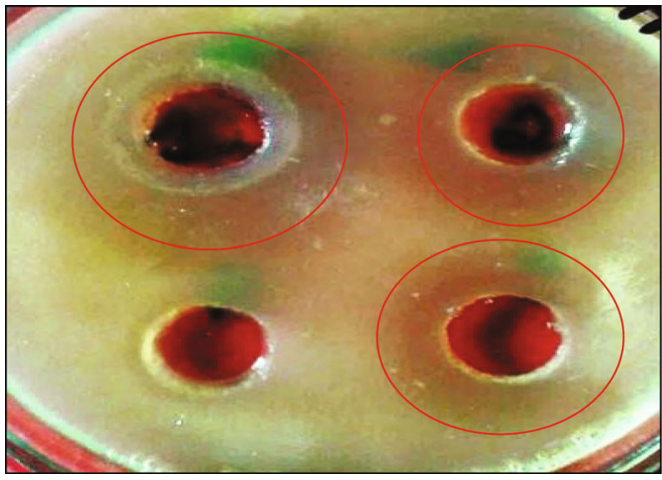

(b)

Figure 17: The pictures of lysis zones of E. amylovora growth around the well on agar medium with $\mathrm{Cu} N \mathrm{NP}$ : (a) $\mathrm{Cu}-\mathrm{H}_{2} \mathrm{O}-\mathrm{EID}$; (b) Cu- $\mathrm{H}_{2} \mathrm{O}-$ gelatin.

ammonia, and alkaline media, both with and without gelatin, showed pronounced activity against the fire blight pathogen bacteria, E. amylovora. The lysis zones ranged from $4.0 \pm 0.10 \mathrm{~mm}$ to $7.0 \pm 0.13 \mathrm{~mm}(P \leq 0.05)$. The absence of bacterial growth was noted at these distances, and vegetative cells formed with morphological deformities closer to the periphery. Microscopic examination revealed disrupted cell morphogenesis: bacterial cells were torn into small pieces and vegetative rods had transformed into cocci.
The large lysis zones observed show that the tested Ag$\mathrm{Cu}$ nanocomposites have sufficiently high biological activity against E. amylovora, $P$ s. syringae, and $P$. carotovorum (Table 7). Among the studied nanopowders, the $\mathrm{Ag}-\mathrm{Cu}$ nanocomposites synthesized in an alkaline medium showed the best results against E. amylovora, Ps. syringae, and $P$. carotovorum. The maximum zone of inhibition reached for each bacteria was $8.0 \pm 0.02 \mathrm{~mm}$ for Ps. syringae, $7.1 \pm 0.92$ $\mathrm{mm}$ for P. carotovorum, and $7.0 \pm 0.14 \mathrm{~mm}$ for E. amylovora 


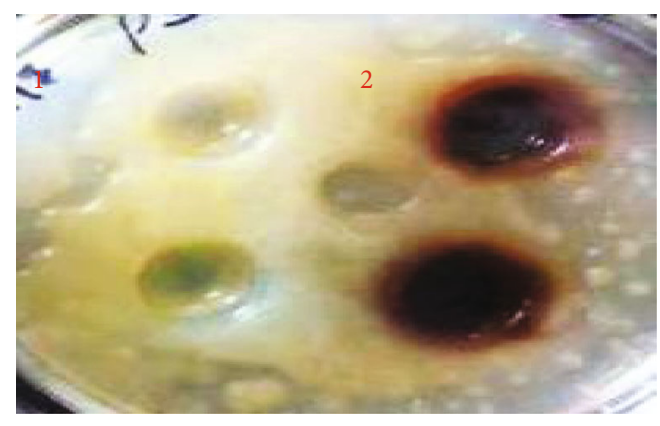

FIGURE 18: The pictures of no lysis zones of Ps. syringae growth around the well on agar medium with chemical preparations: (1) Xerox colloidal silver preparation; (2) copper sulfate.

$(P \leq 0.05)$. The antibacterial activity of the Ag-Cu nanocomposites was three to four times higher than the antibacterial activity of the Ag MNPs at $1 \mathrm{mg} / \mathrm{ml}$.

Thus, the combined chemical reduction of $\mathrm{Ag}$ and $\mathrm{Cu}$ ions in the presence of gelatin leads to an increase in the antibacterial activity of Ag-Cu nanocomposites. The minor NP aggregates formed in an alkaline medium exhibited the highest antibacterial activity against all tested bacterial pathogens (Figures 19 and 20).

When smears were taken from bacterial colonies around the lysis zones and the bacteria examined and compared to those from colonies of control plates, significant differences were observed in the places of contact between NPs and bacteria. As shown in Figures 21 and 22, the bacterial morphology changed dramatically when the bacteria were exposed to NPs. The E. amylovora rod-shaped cells were crushed into cocci shapes or became shapeless. Moreover, the Ps. syringae cells lost their normal form and turned into an amorphous mass. In this case, the bacteria also lost their normal activity. It is reasonable to assume that the processes of division and reproduction were disrupted, given that metallic NPs are known to affect the bacterial DNA structure.

3.2.5. The Effects of Ag and Cu NPs on Wheat and Corn Seed Germination and Growth. Seed germination and seedling growth are widely used to test the phytotoxicity of chemical species, such as engineered nanomaterials that may be released into the environment. Measurement of seed germination and shoot and root elongation are relatively rapid methods for determining acute phytotoxicity, and they have several advantages: sensitivity, simplicity, low cost, and suitability for reactive chemicals and contaminated soil samples [27].

The greatest wheat germination and seedling growth resulted from exposure to the $S$. diastochromogenes suspension. Root length reached $17.1 \pm 1.02 \mathrm{~cm}$ in 10 days, and shoot size $15.0 \pm 1.09 \mathrm{~cm}$. The seed germination rate was $99.9 \pm$ 0.09\% $(P \leq 0.05)$. An interesting phenomenon was observed in this treatment compared with other specimens: the stems were very thick. The second biological agent-S. violaceoruber-also showed a significant growth-stimulating effect; however, it was less than that of the first natural agent (Table 8).

Of all the tested NPs, the Ag-Cu BNP (acidic) composition exhibited the greatest growth-stimulating effect on the wheat roots and stems. In 10 days, the root length reached $15.0 \pm 1.05 \mathrm{~cm}$ and the stem length reached $15.0 \pm 1.25 \mathrm{~cm}$ $(P<0.05) \quad(n=3)$. The seed germination was also higher $(95.4 \pm 0.13 \%, P<0.05)$ than that observed for other NP samples, but it was lower than that for the biological products. The Ag MNP solution was found to positively affect the germination of wheat seeds; the germination rate was $99.8 \pm 0.05 \%(P<0.05)$ (see Figure S1 in the Supplementary Material).

The effectiveness of the $\mathrm{Ag}-\mathrm{Cu}$ (neutral) and $\mathrm{Ag}-\mathrm{Cu}$ (alkaline) BNPs was much lower than that of the $\mathrm{Ag}-\mathrm{Cu}$ (acidic) BNPs and the Ag MNPs. However, both of these compositions stimulated wheat stem growth but not root growth (see Figure S2 in the Supplementary Material). The thickness of the stems was very different from that observed in the controls, reaching some $\mathrm{mm}$ in diameter. The root length of the control (water) was $3.0 \pm 0.15 \mathrm{~cm}$, the shoot length was $15.0 \pm 1.09 \mathrm{~cm}$, and the germination was $90.0 \pm$ $0.08 \%(P<0.05)$ (Figures 23-25).

In general, there was a decrease in seed germination when NPs were used, except for Ag MNPs. In terms of phytotoxicity, the NP solutions $(1 \mathrm{mg} / \mathrm{l})$ were more phytotoxic than the biological products $\left(1 \times 10^{3}\right.$ spores $\left./ \mathrm{ml}\right)$ for wheat seeds.

The results were significantly different when corn seeds were used. The Ag MNPs showed the highest growthstimulating effect. The root and stem lengths reached 15.0 $\pm 0.78 \mathrm{~cm}$ and $15.0 \pm 0.92 \mathrm{~cm}$, respectively, in 10 days with three repetitions. However, the germination of corn seeds was less than that of wheat seeds, at $80.1 \pm 0.12 \%(P<0.05$ ) (Table 9).

The Ag-Cu (neutral) BNP composition also had a significant effect on the growth of the plant vegetative organs. The root length was $12.0 \pm 0.67 \mathrm{~cm}$ and the stem size was 15.0 $\pm 1.41 \mathrm{~cm}(P<0.05)$. However, the germination was even lower than that resulting from exposure to the Ag MNPs. The Ag-Cu (alkaline) BNP composition was found to be considerably phytotoxic, with the lowest germination rate of $60.0 \pm 0.16 \mathrm{~cm}(P<0.05)$.

The bioproducts of $S$. diastochromogenes induced a corn seed germination rate of $99.7 \pm 0.09 \%$, although the growthstimulating effect was lower than that of the NPs. The germination of corn seeds in the control was $80.2 \pm 0.31 \%$, the root length was $4.0 \pm 0.17 \mathrm{~cm}$ and the shoot size was 15.0 $\pm 1.06 \mathrm{~cm}(P<0.05)$. The $\mathrm{Ag} \mathrm{MNPs}$ and $\mathrm{Cu} \mathrm{MNPs}$ had the same effect on germination as the water control; that is, the toxic effect was not noticeable (Figures 26-28).

\section{Discussion}

The antibacterial effects of $\mathrm{Ag}$ and $\mathrm{Cu}$ have been known since ancient times. $\mathrm{Cu}$ is involved in the metabolism of all living organisms, and it is primarily involved in fermentation [19]. Cu salts are used in agriculture for seed treatment as chemical fungicides and in prophylactic therapies against phytopathogens of fruit crops and other agricultural plants. Chemical compounds containing $\mathrm{Ag}$ and $\mathrm{Cu}$ are also used in medicine, food processing, environmental protection, and other areas $[12,13,19,28,41]$. 


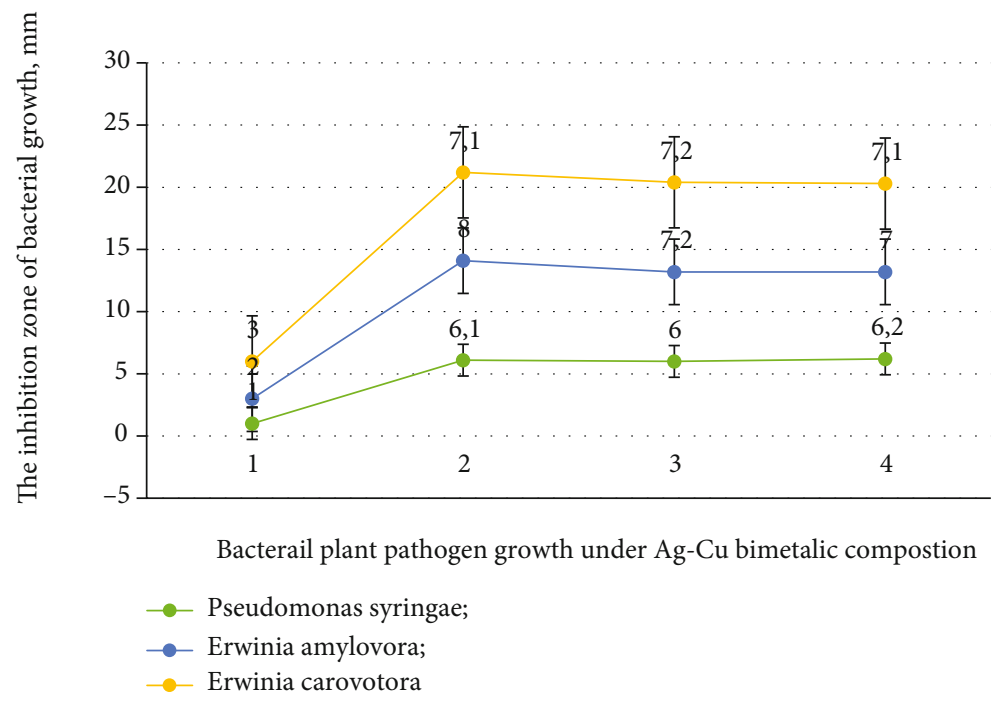

Figure 19: Effects of $\mathrm{Ag}$ and $\mathrm{Cu} \mathrm{NPs}(1 \mathrm{mg} / \mathrm{l})$ on bacterial diseases of various plants: 1: Ag and Cu MNPs; 2: Ag-Cu, gelatin in NaOH; 3: Ag$\mathrm{Cu}$, gelatin in $\mathrm{NH}_{4} \mathrm{OH}$; $4 \mathrm{Ag}-\mathrm{Cu}$, gelatin in neutral reaction medium.

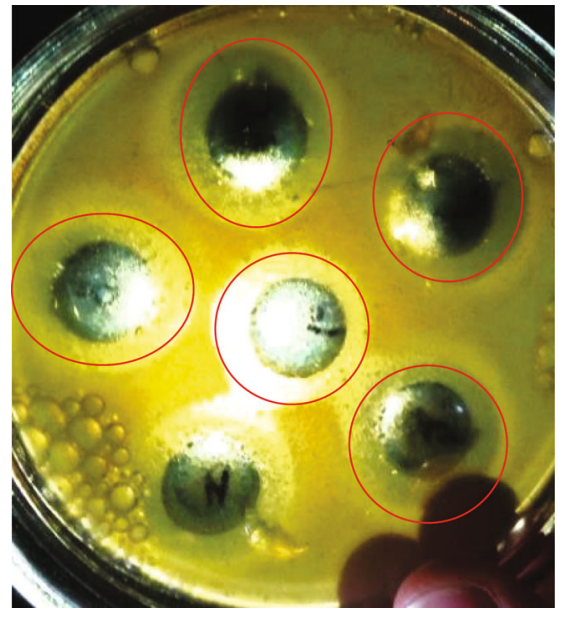

(a)

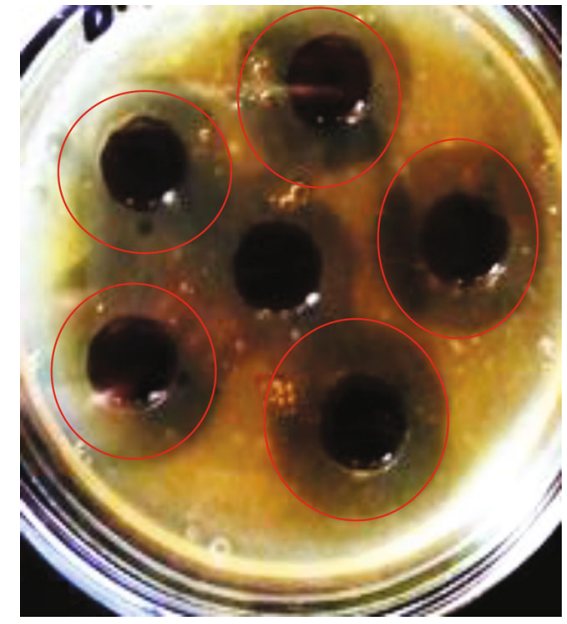

(b)

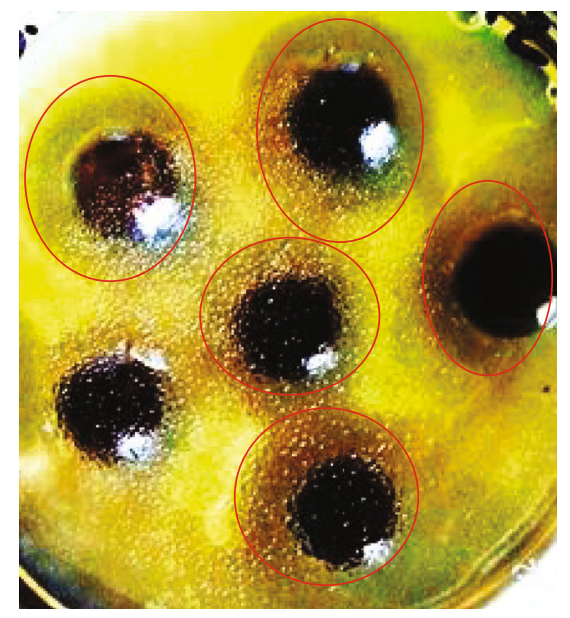

(c)

Figure 20: The pictures of the lysis zone of bacterial growth around the well agar medium with BNPs (Ag-Cu, gelatin in NaOH): (a) Erwinia amylovora; (b) Pseudomonas syringae; (c) Pectobacterium carotovorum. 


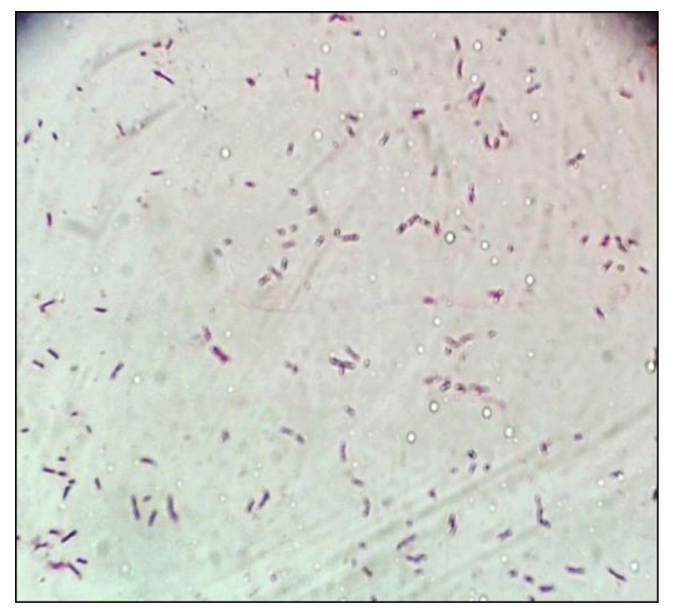

(a)

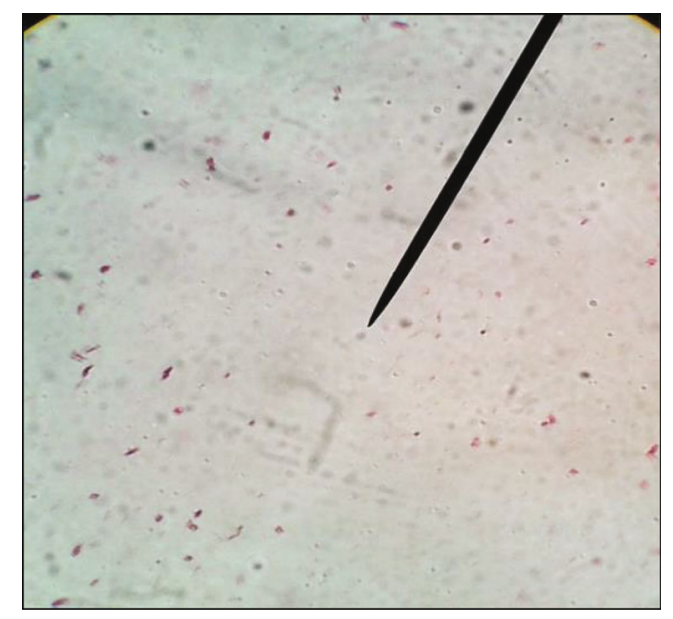

(b)

FIgURE 21: (a) Microscopic rods of the bacterium Erwinia amylovora in control; (b) bacterium Erwinia amylovora in contact with nanoparticles.

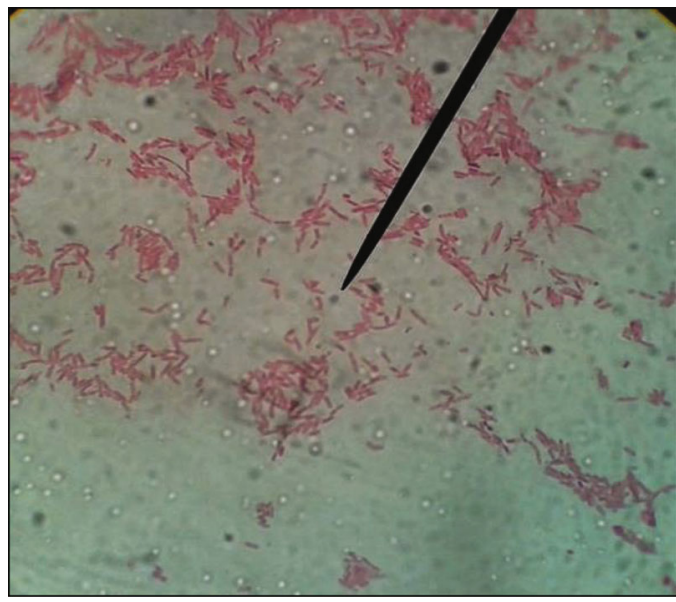

(a)

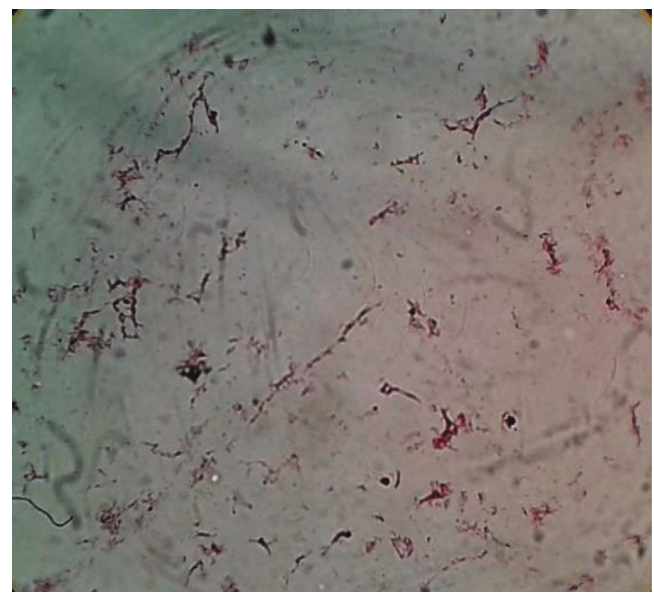

(b)

Figure 22: (a) Microscopic rods of the bacterium Pseudomonas syringae in control; (b) bacterium Pseudomonas syringae in contact with nanoparticles.

TABLE 8: Effects of Ag and Cu MNPs and Ag-Cu BNPs on the germination and growth of wheat seeds compared with bioproducts ( $n=3$ ).

\begin{tabular}{|c|c|c|c|c|}
\hline Variant & Concentration & Root length $(\mathrm{cm})$ & Stem length $(\mathrm{cm})$ & Germination (\%) \\
\hline Control (water) & & $3.0 \pm 0.15$ & $15.0 \pm 1.09$ & $90.2 \pm 0.08$ \\
\hline Ag MNP & $1 \mathrm{mg} / \mathrm{l}$ & $10.1 \pm 0.97$ & $12.0 \pm 1.03$ & $99.8 \pm 0.05$ \\
\hline $\mathrm{Cu} \mathrm{MNP}$ & $1 \mathrm{mg} / \mathrm{l}$ & $8.0 \pm 0.76$ & $14.0 \pm 1.21$ & $90.2 \pm 0.07$ \\
\hline Ag-Cu BNP (acidic) & $1 \mathrm{mg} / \mathrm{l}$ & $15.0 \pm 1.05$ & $15.0 \pm 1.25$ & $95.4 \pm 0.13$ \\
\hline Ag-Cu BNP (neutral) & $1 \mathrm{mg} / \mathrm{l}$ & $5.0 \pm 0.89$ & $15.0 \pm 1.31$ & $90.1 \pm 0.16$ \\
\hline Ag-Cu BNP (alkaline) & $1 \mathrm{mg} / \mathrm{l}$ & $8.0 \pm 0.15$ & $13.0 \pm 1.07$ & $95.0 \pm 0.15$ \\
\hline Streptomyces violaceoruber & $1 \times 10^{3}$ spores $/ \mathrm{ml}$ & $10.2 \pm 0.94$ & $15.0 \pm 0.92$ & $99.8 \pm 0.04$ \\
\hline Streptomyces diastochromogenes & $1 \times 10^{3}$ spores $/ \mathrm{ml}$ & $17.1 \pm 1.02$ & $15.0 \pm 1.09$ & $99.9 \pm 0.09$ \\
\hline
\end{tabular}




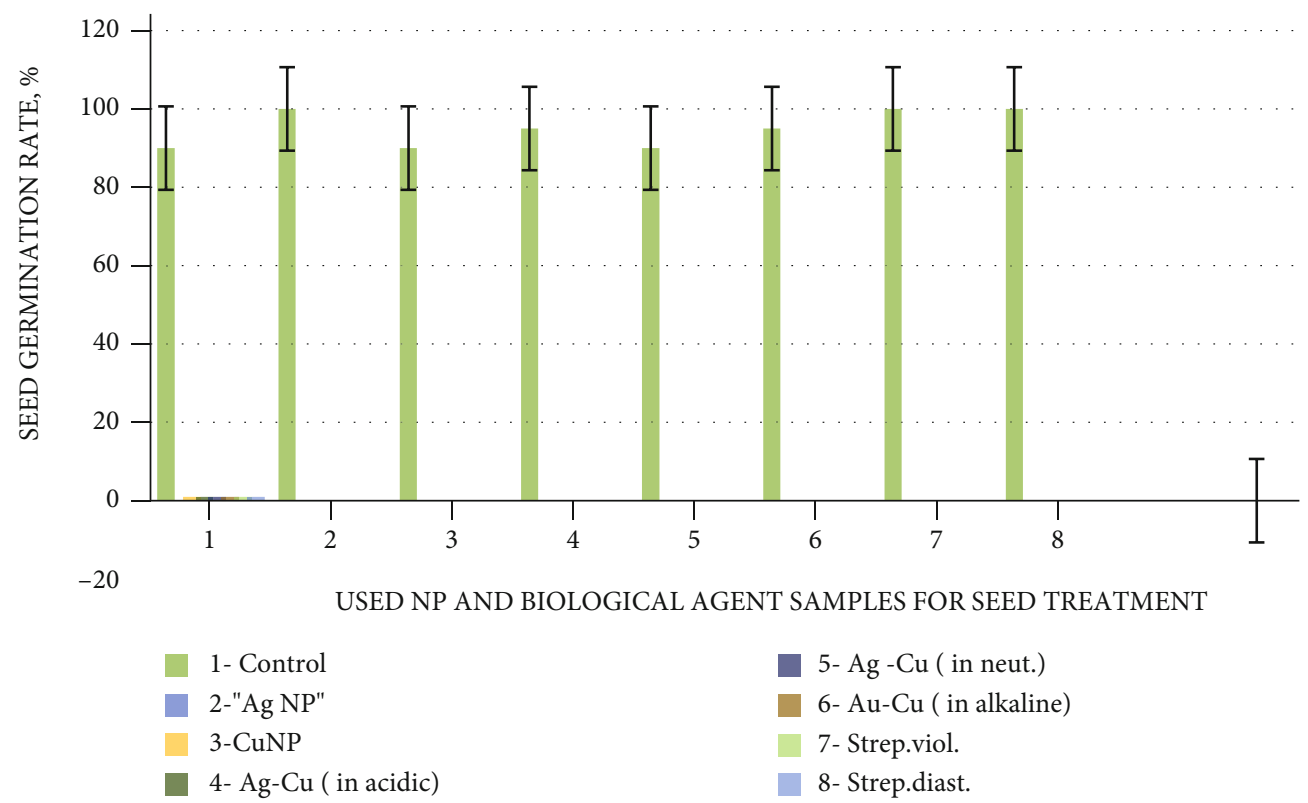

Figures 23: The germination rate of wheat seeds under treatments by MNPs, BNPs, and biological agents.

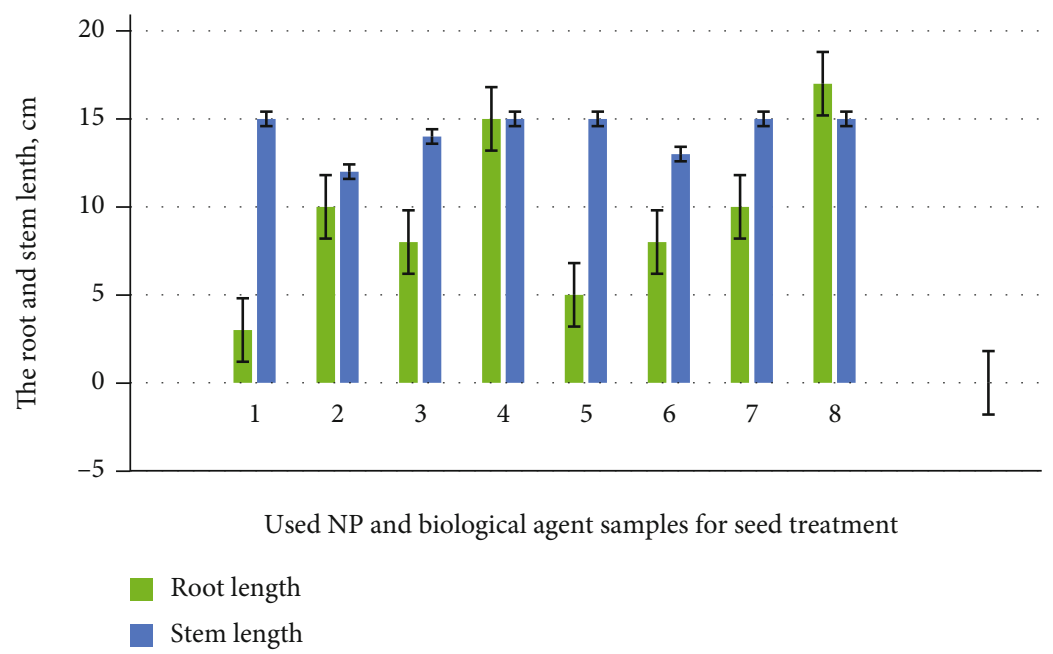

FiguREs 24: The growth-regulator effects of metallic nanoparticles and biological agents on wheat seedlings by treatments: 1: control; 2: Ag $\mathrm{NP}$; 3: $\mathrm{Cu} \mathrm{NP}$; 4: $\mathrm{Ag}-\mathrm{Cu}$ (in acidic); 5: Ag-Cu (in neutral); 6: Ag-Cu (in alkaline); 7: Streptomyces violaceoruber; 8: Streptomyces diastochromogenes.

The development of modern nanotechnology is aimed at producing NPs and nanoscale structures of metals.

In the present study, $\mathrm{Ag}$ and $\mathrm{Cu}$ MNPs and BNPs were synthesized using different methods and media and their antibacterial activities were studied. For the first time, Ag$\mathrm{Cu}$ BNPs were investigated for their antibacterial activities against Gram-negative plant pathogenic bacteria: Ps. syringae, P. carotovorum, and E. amylovora.

When $\mathrm{Ag}$ and $\mathrm{Cu}$ MNPs were tested, it was found that only MNPs at a high concentration $(5 \mathrm{mg} / \mathrm{l})$ that were synthesized in a neutral reaction and stabilized in gelatin showed significant activity $(P<0.05)$ against $P$ s. syringae. The Ag MNPs had low activity against $P$. carotovorum and E. amylovora. Statistical analysis of variance with 0.05 significance showed that a $5 \mathrm{mg} / \mathrm{l} \mathrm{Ag} \mathrm{MNP}$ concentration had a common inhibition effect on P. carotovorum and E. amylovora. Ag MNPs synthesized in a neutral medium (Ag$\left.\mathrm{H}_{2} \mathrm{O}\right)$ and in an ammonia medium $\left(\mathrm{Ag}-\mathrm{NH}_{4} \mathrm{OH}\right)$ at $5 \mathrm{mg} / \mathrm{l}$ manifested antibacterial properties against $P$ s. syringae and P. carotovorum $(P<0.05)$.

The antibacterial activity of the Ag MNPs was enhanced when gelatin was included as a stabilizer in the neutral $\mathrm{pH}$ reaction. These results confirm the importance of including stabilizers for the production of biocompatible NPs with physiological activity; they enhance the biological properties of NPs [42]. It is worth noting that in the current study, the enhancing role of gelatin for Ag MNPs was only observed against Gram-negative Ps. syringae. Others have reported a higher antibacterial effect on Gram-negative bacteria due to electrostatic interactions between positively charged NPs 


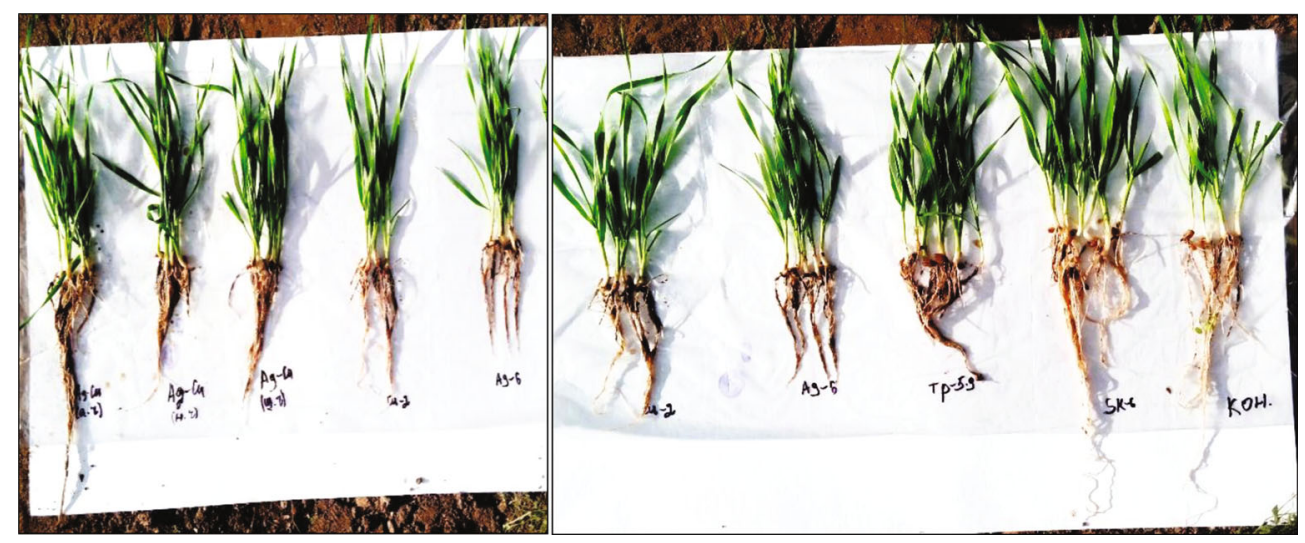

Figures 25: The growth of roots and aboveground parts of wheat under the treatment by Ag, Cu nanoparticle solutions, and bioproducts of Streptomyces bacteria.

TABle 9: Effects of Ag and Cu MNPs and Ag-Cu BNPs on the germination and growth of corn seeds compared with bioproducts $(n=3)$.

\begin{tabular}{lcccc}
\hline Variant & Concentration & Root length $(\mathrm{cm})$ & Stem length $(\mathrm{cm})$ & Germination $(\%)$ \\
\hline Control (water) & & $4.0 \pm 0.17$ & $15.0 \pm 1.06$ & $80.2 \pm 0.31$ \\
Ag MNP & $1 \mathrm{mg} / \mathrm{l}$ & $15.0 \pm 0.78$ & $15.0 \pm 0.92$ & $80.1 \pm 0.12$ \\
Cu MNP & $1 \mathrm{mg} / \mathrm{l}$ & $10.0 \pm 0.78$ & $15.0 \pm 1.1$ & $80.0 \pm 0.17$ \\
Ag-Cu BNP (acidic) & $1 \mathrm{mg} / \mathrm{l}$ & $8.0 \pm 1.13$ & $13.0 \pm 1.14$ & $70.2 \pm 0.34$ \\
Ag-Cu BNP (neutral) & $1 \mathrm{mg} / \mathrm{l}$ & $12.0 \pm 0.67$ & $15.0 \pm 1.41$ & $70.3 \pm 0.70$ \\
Ag-Cu BNP (alkaline) & $1 \mathrm{mg} / \mathrm{l}$ & $8.0 \pm 0.14$ & $15.0 \pm 1.12$ & $60.0 \pm 0.16$ \\
Streptomyces diastochromogenes & $1 \times 10^{3}$ spores $/ \mathrm{ml}$ & $10.2 \pm 1.05$ & $12.0 \pm 1.14$ & $99.7 \pm 0.09$ \\
Streptomyces violaceoruber & $1 \times 10^{3}$ spores $/ \mathrm{ml}$ & $10.2 \pm 1.79$ & $14.1 \pm 1.09$ & $80.2 \pm 0.07$ \\
\hline
\end{tabular}

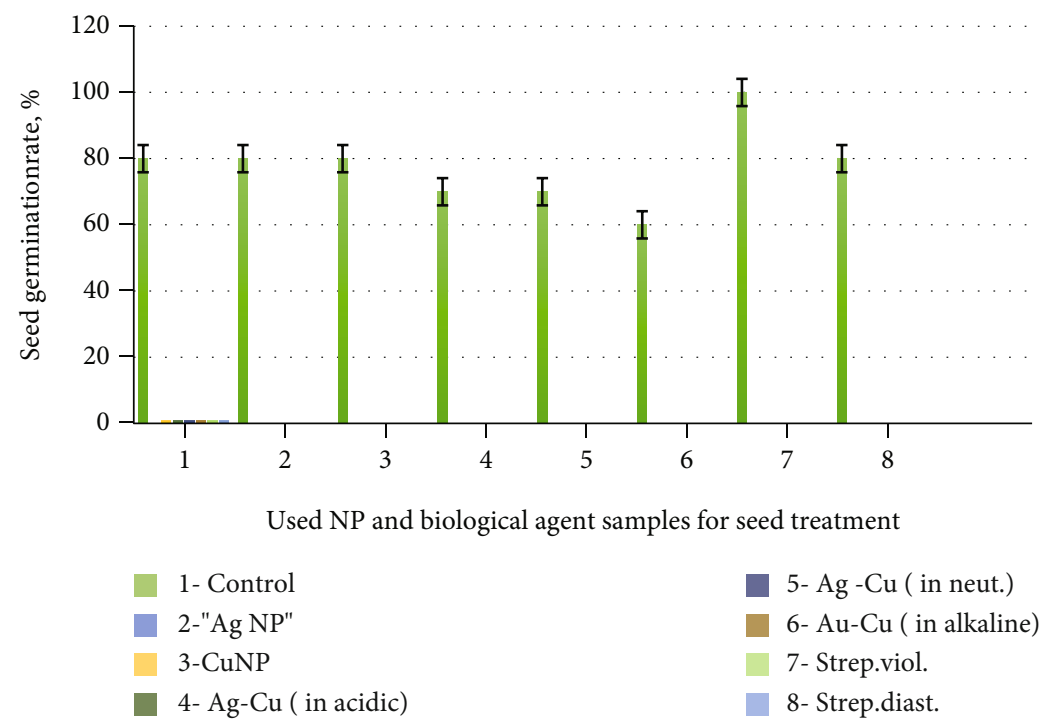

Figures 26: The germination rate of corn seeds under treatments by MNPs, BNPs, and biological agents. 


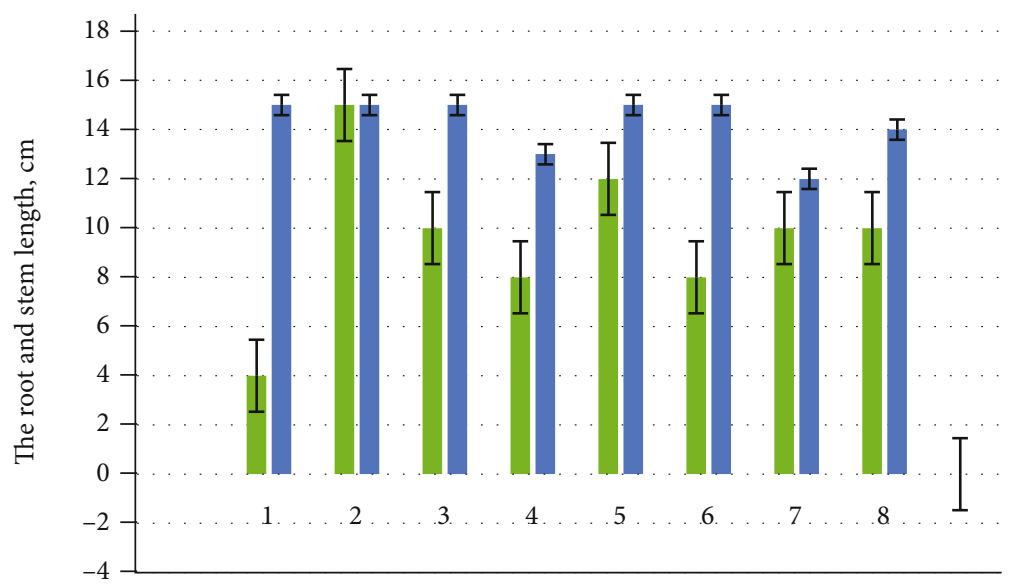

Used NP and biological agent samples for seed treatment

$$
\begin{aligned}
& \text { Root length } \\
& \text { - Stem length }
\end{aligned}
$$

FiguREs 27: The growth-regulator effects of metallic nanoparticles and biological agents on corn seedlings by treatments: 1: control; 2: Ag $\mathrm{NP}$; 3: $\mathrm{Cu} \mathrm{NP}$; 4: $\mathrm{Ag}-\mathrm{Cu}$ (in acidic); 5: $\mathrm{Ag} \mathrm{Cu}$ (in neutral); 6: $\mathrm{Ag}-\mathrm{Cu}$ (in alkaline); 7: Streptomyces violaceoruber; 8: Streptomyces diastochromogenes.

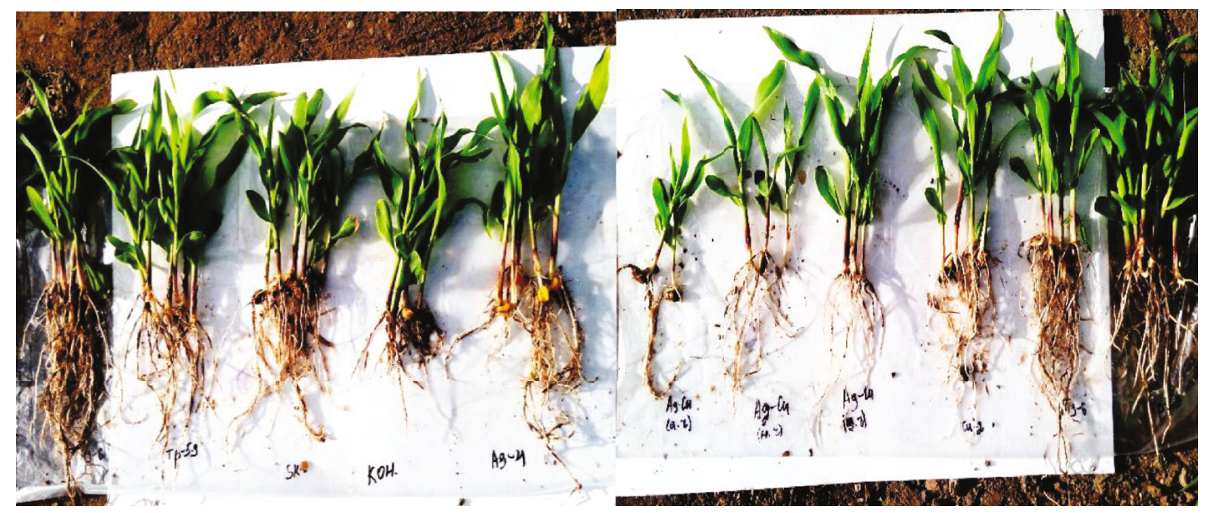

FiguREs 28: The growth of roots and aboveground parts of corn under the treatment by Ag, Cu nanoparticle solutions, and bioproducts of Streptomyces bacteria.

and the negatively charged bacterial membrane. Because of the exchange, the permeability of cell membranes is disrupted, destroying the cell wall and damaging DNA replication [36, 43-45]. However, in this study, even high concentrations of Ag MNPs did not have a bactericidal effect on the bacterial fire blight pathogen E. amylovora. Hence, the findings indicate that not all Gram-negative bacteria are sensitive to Ag MNPs. Of the three bacteria tested, Ps. syringae was the most susceptible. As noted by others, the response or sensitivity of each bacterial species to NPs depends on their metabolic characteristics [46-49].

When the $\mathrm{Cu}$ MNP results were analyzed, it was found that the biological properties and effective antibacterial concentrations of these MNPs differed sharply from those of the Ag MNPs. Unlike Ag MNPs, Cu MNPs at 0.5, 1.0 and $5.0 \mathrm{mg} / \mathrm{l}$ exhibited antibacterial activity. Where Ag MNPs were found to be active mainly against the causative agent of bacterial canker (Ps. syringae), Cu MNPs showed high activity against the causative agent of bacterial fire blight
(E. amylovora). In addition, in contrast to the Ag MNPs, the $\mathrm{Cu}$ NPs synthesized in different media and stabilized and unstabilized showed activity against all three tested pathogens. In particular, the $\mathrm{Cu}-\mathrm{H}_{2} \mathrm{O}$ MNPs at $1-5 \mathrm{mg} / \mathrm{l}$ showed the highest activity of all the $\mathrm{Cu}$ MNPs.

The Ag-Cu BNPs exhibited significantly higher activity than the MNPs. Even at a low concentration $(1 \mathrm{mg} / \mathrm{l})$ the composites showed significant activity against all three tested pathogens. The Ag-Cu nanocomposites synthesized in an alkaline medium demonstrated the highest activity against all three pathogens. The minor aggregates produced in the alkaline medium had the highest antibacterial activity against E. amylovora and Ps. syringae. Thus, these results have confirmed other reports of a significant difference in the biological activity of MNPs and BNPs. This suggests that, compared to MNPs, BNPs contain unique and additional characteristics that complement each other in terms of physiological properties. For example, electron transfer from Ag NPs to second metal NPs can enhance the 
antibacterial activity of nanocomposites [23]. Therefore, it is more desirable to use BNPs at low concentrations in agricultural practice than MNPs.

We also examined the phytotoxic and phytoregulatory effects of the NPs on wheat and corn seeds to clarify the possibility of using NPs for presowing seed treatment. At $1 \mathrm{mg} / \mathrm{l}$, the NPs were not phytotoxic to wheat seeds; in fact, the opposite was found. At this concentration, the NPs showed a growth-stimulating effect on the germination of seeds and the growth of young roots and shoots, although the NPs were inferior to the Streptomyces rhizosphere biological agents. However, when tested on corn seeds, the bimetallic compositions showed greater phytotoxicity than the monometallic materials; this feature should be considered in practical applications.

Some studies have demonstrated the protective and stimulating effects of $\mathrm{Ag}$ nanocomposites on the growth and development of wheat and other crops [27, 49, 50]. Others have confirmed that, unlike ionic biogenic metals, NPs have prolonged action and lower toxicity than metal salts and can activate physiological and biochemical processes in plants [24]. The Ag NP concentrations that are toxic to plant seeds have also been determined in some cases; for example, $10 \mathrm{mg} / \mathrm{l}$ suppressed the germination and growth of seedlings of Hordeum vulgare and Linum usitatissimum [3].

According to existing data, the effects of NPs on plants depend on the plant species and age, NP concentration and duration, and method of exposure. There are different and often conflicting reports on the accumulation and toxicity of NPs in plant species [29]. Our corn seed germination and corn seedling growth results are in alignment with those of other studies [29] that showed that Ag NPs had a toxic effect on corn root elongation. In contrast, the same Ag NP concentration has been shown to have a positive effect on watermelon and zucchini seedling growth, leading to the conclusion that Ag NPs exhibit both positive and negative effects on plant growth and germination.

Our results have shown that $1 \mathrm{mg} / \mathrm{l}$ is the ideal concentration of Ag MNPs and Ag-Cu BNPs for the treatment of wheat. The application of NPs at this concentration improved the percentage of seed germination and the growth of seedlings. This concentration was found to be slightly toxic for corn when the seeds were soaked for $2 \mathrm{~h}$. According to existing reports, NPs promote the absorption of water by grains, increase the content of nitrate reductase, and support the development of antioxidants [51, 52].

\section{Conclusions}

The current study has shown that $\mathrm{Cu}$ and Ag MNPs and BNPs are effective against several pathogens that pose a threat to fruit trees and vegetable crops in Kyrgyzstan: $E$. amylovora (bacterial fire blight), Ps. syringae (bacterial canker), and $P$. carotovorum (rotten vegetable bacterium).

At $5 \mathrm{mg} / \mathrm{l}$, the $\mathrm{Ag}$ MNPs $\mathrm{Ag}-\mathrm{H}_{2} \mathrm{O}$ and $\mathrm{Ag}-\mathrm{NH}_{4} \mathrm{OH}$ showed high antibacterial activity against $P$ s. syringae, whereas $\mathrm{Ag}-\mathrm{H}_{2} \mathrm{O}-\mathrm{ERD}$ at $1 \mathrm{mg} / \mathrm{l}$ and $\mathrm{Cu}-\mathrm{H}_{2} \mathrm{O}-\mathrm{ERD}$ at $0.1 \mathrm{mg} / \mathrm{l}$ exhibited a high inhibition effect against E. amylo- vora. Ag-Cu bimetallic compositions were found to be very active against all tested bacterial pathogens. In particular, the Ag-Cu gelatin (neutral medium), Ag-Cu gelatin (ammonia medium), and $\mathrm{Ag}-\mathrm{Cu}$ gelatin (alkaline medium) samples showed high antibacterial activity against the most harmful pathogen-E. amylovora.

Our results suggest that, due to their antibacterial activity, Ag-Cu nanocomposites could be useful additions to numerous agricultural applications that are aimed at protecting crops from dangerous diseases, such as seed coating and the treatment of plant roots and aboveground organs. We have also shown that advances in nanotechnology now allow for the development of new, safe, ecologically friendly, multifunctional material formulations. Therefore, bimetallic nanocomposites should be considered as alternatives to the harmful chemicals used in agriculture to protect crops from pathogenic bacteria.

This study has shown that a nanocomposite based on $\mathrm{Ag}$ and $\mathrm{Cu}$ can be used as an environmentally friendly, protective, growth-stimulating, new-generation antimicrobial formulation for treating agricultural plants.

\section{Data Availability}

The data used to support the findings of this study are included within the article.

\section{Conflicts of Interest}

The authors declare that there is no conflict of interest regarding the publication of this paper.

\section{Acknowledgments}

The authors gratefully acknowledge financial support by the Ministry of Education and Science of the Kyrgyz Republic grant number 7323. The authors thanks Kumamoto University for X-ray diffraction and the scanning electron microscopy analyses.

\section{Supplementary Materials}

Biological activity of $\mathrm{Ag}$ and $\mathrm{Cu}$ monometallic nanoparticles and Ag-Cu bimetallic nanocomposites against plant pathogens and seed article. (Supplementary Materials)

\section{References}

[1] N. G. Khlebtsov, "Gold nanostructures with plasmon resonance for biomedical research," Russian Nanotechnologies, vol. 2, no. 3-4, pp. 69-86, 2007, (in Russia).

[2] B. Syed, N. Bisht, P. S. Bhat et al. , "Phytogenic synthesis of nanoparticles from _Rhizophora mangle_ and their bactericidal potential with DNA damage activity," Nano-Structures \& Nano-Objects., vol. 10, pp. 112-115, 2017.

[3] A. I. El-Batal, G. S. El-Sayyad, F. M. Mosallam, and R. M. Fathy, "Penicillium chrysogenum mediated mycogenic synthesis of copper oxide nanoparticles using gamma rays for in vitro antimicrobial activity against some plant pathogens," Journal of Cluster Science, vol. 31, pp. 79-90, 2020. 
[4] K. Madhumathi, S. Kumar, S. Abhilash et al., "Development of novel chitin/ nanosilver composite scaffolds for wound dressing applications," Journal of Materials Science, vol. 21, no. 2, pp. 807-813, 2010.

[5] A. Llorens, E. Lloret, P. A. Picouet, R. Trbojevich, and A. Fernandez, "Metallic-based micro and nanocomposites in food contact materials and active food packaging," Trends in Food Science \& Technology, vol. 24, no. 1, pp. 19-29, 2012.

[6] M. L. Knetsch and L. H. Koole, "New strategies in the development of antimicrobial coatings the example of increasing usage of silver and silver nanoparticles," Polymers, vol. 3, no. 1, pp. 340-366, 2011.

[7] A. M. Jastrzębska, E. Karwowska, A. R. Olszyna, and A. R. Kunicki, "Comparative Assessment of Antimicrobial Efficiency of Ionic Silver, Silver Monoxide, and Metallic Silver Incorporated onto an Aluminum Oxide Nanopowder Carrier," Journal of Nanoscience and Nanotechnology, vol. 2013, article 263583, pp. 1-12, 2013.

[8] A. Costescu, C. S. Ciobanu, S. L. Iconaru et al., "Fabrication, Characterization, and Antimicrobial Activity, Evaluation of Low Silver Concentrations in Silver-Doped Hydroxyapatite Nanoparticles," Journal of Nanomaterials, vol. 2013, Article ID 194854, 9 pages, 2013.

[9] Z. M. Xiu, Q. B. Zhang, H. L. Puppala, V. L. Colvin, and P. J. J. Alvarez, "Negligible particle-specific antibacterial activity of silver nanoparticles," Nano Letters, vol. 12, no. 8, pp. 42714275, 2012.

[10] J. López-Esparza, L. F. Espinosa-Cristóba, A. Donohue-Cornejo, and S. Y. Reyes-López, "Antimicrobial activity of silver nanoparticles in polycaprolactone nanofibers against Grampositive and Gram-negative bacteria," Industrial \& Engineering Chemistry Research, vol. 55, no. 49, pp. 12532-12538, 2016.

[11] R. Srivastava, D. K. Tiwari, and D. K. Dutta, "4-(Ethoxycarbonyl) phenyl-1-amino-oxobutanoic acid-chitosan complex as a new matrix for silver nanocomposite film: Preparation, characterization and antibacterial activity," International Journal of Biological Macromolecules, vol. 49, no. 5, pp. 863-870, 2011.

[12] S. Mureed, S. Naz, A. Haider et al., "Development of multiconcentration $\mathrm{Cu}: \mathrm{Ag}$ bimetallic nanoparticles as a promising bactericidal for antibiotic-resistant bacteria as evaluated with molecular docking study," Nanoscale Research Letters, vol. 16, no. 1, p. 91, 2021.

[13] K. Vimala, Y. M. Mohan, K. Sivudu et al., "Fabrication of porous chitosan films impregnated with silver nanoparticles: a facile approach for superior antibacterial application," Colloids and Surfaces B: Biointerfaces, vol. 76, no. 1, pp. 248258, 2010.

[14] A. Tamilvanan, K. Balamurugan, K. Ponappa, and B. M. Kumar, "Copper nanoparticles: synthetic strategies, properties and multifunctional application," International Journal of Nanoscience, vol. 3, p. 1430001, 2014.

[15] M. S. P. Boyles, C. Ranninger, R. Reischl et al., "Copper oxide nanoparticle toxicity profiling using untargeted metabolomics," Particle and Fibre Toxicology, vol. 13, no. 1, p. 49, 2015.

[16] J. P. Ruparelia, A. K. Chatterjee, S. P. Duttagupta, and S. Mukherji, "Strain specificity in antimicrobial activity of silver and copper nanoparticles," Acta Biomaterialia, vol. 4, no. 3, pp. 707-716, 2008.

[17] M. J. Hajipour, K. M. Fromm, A. A. Ashkarran et al., "Antibacterial properties of nanoparticles," Trends in Biotechnology, vol. 30, no. 10, pp. 499-511, 2012.
[18] K. Y. Yoon, J. H. Byeon, J.-H. Park, and J. Hwang, "Susceptibility constants of _Escherichia coli_and_Bacillus subtilis_to silver and copper nanoparticles," Science of the Total Environment, vol. 373, no. 2-3, pp. 572-575, 2007.

[19] R. J. B. Pinto, S. Daina, P. Sadocco, C. P. Neto, and T. Trindade, "Antibacterial activity of nanocomposites of copper and cellulose," BioMed Research International, Article ID, vol. 2013, pp. 1-6, 2013.

[20] Y. M. Hafez, A. Salama, H. Kotb et al., "The influence of nanocopper and safety compounds of vegetative growth yield and fruit quality of Le Conte pear trees under infection with fire blight, by PSP," Fresenius Environmental Bulletin and Advances in Food Sciences, vol. 30, no. 6, pp. 6237-6247, 2021.

[21] R. Roy, R. A. Roy, and D. M. Roy, "Alternative perspectives on "quasi-crystallinity": Non-uniformity and nanocomposites," Materials Letters, vol. 4, no. 8-9, pp. 323-328, 1986.

[22] U. Gupta, H. B. Agashe, A. Asthana, and N. K. Jain, “A review of in vitro-in vivo investigations on dendrimers: the novel nanoscopic drug carriers," Nanomedicine, vol. 2, no. 2, pp. 66-73.

[23] G. Sharma, A. Kumar, D. Pathania, and M. Sillanpa, "[email protected](IV) vanadophosphate nanocomposite: Ion exchange properties, antibacterial activity, and photocatalytic behavior," Journal of Industrial and Engineering Chemistry, vol. 33, pp. 201-208, 2016.

[24] K. S. Kavitha, S. Baker, D. Rakshith et al., "Plants as green source towards synthesis of nanoparticles," International Research Journal of Biological Sciences, vol. 2, pp. 66-76, 2013.

[25] S. Baker and S. Satish, "Endophytes: toward a vision in synthesis of nanoparticle for future therapeutic agents," International Journal of Bio-Inorganic Hybrid Nanomaterials., vol. 2, pp. 6777, 2012.

[26] A. I. Perfileva, O. A. Nozhkina, I. A. Graskova et al., "Synthesis of selenium and silver nanobiocomposites and their influence on phytopathogenic bacterium Clavibacter michiganensis subsp. sepedonicus," Russian Chemical Bulletin, vol. 67, no. 1, pp. 157-163, 2018.

[27] O. Munzuroglu and H. Geckil, "Effects of metals on seed Germination, Root elongation, and coleoptile and hypocotyl growth in Triticum aestivum and Cucumis sativus," Archives of Environmental Contamination and Toxicology, vol. 43, no. 2, pp. 203-213, 2002.

[28] A. Raghunath and E. Perumal, "Metal oxide nanoparticles as antimicrobial agents: a promise for the future," International Journal of Antimicrobial Agents, vol. 49, no. 2, pp. 137-152.

[29] Z. M. Almutairi and A. Alharbi, "Effect of silver nanoparticles on seed germination of crop plants," Journal of Advances in Agriculture, vol. 4, no. 1, pp. 280-285, 2015.

[30] Z. K. Zhasnakunov and A. S. Satyvaldiev, Method of obtaining nanocompsites of silver and copper, Kyrgyz Republic Patent, 2018.

[31] Z. K. Zhasnakunov and A. S. Satyvaldiev, Method of obtaining metal nanocompsites based on silver, Kyrgyz Republic Patent, 2018.

[32] ISTA, "[International Seed Testing Association], "international rules for seed testing", Seed Science and Technology, vol. 21, pp. 1-288, 1996.

[33] Y. Chang, M. L. Lye, and H. C. Zeng, "Large-scale synthesis of high-quality Ultralong copper nanowires," Langmuir, vol. 21, no. 9, pp. 3746-3748, 2005. 
[34] D. Mott, J. Galkowski, L. Wang, J. Luo, and C. Zhong, "Synthesis of size-controlled and shaped copper nanoparticles," Langmuir, vol. 23, no. 10, pp. 5740-5745, 2007.

[35] M. G. Guzmán, J. Dille, and S. Godet, "Synthesis of silver nanoparticles by chemical reduction method and their antibacterial activity," International Journal of Chemical and Biomolecular Engineering, vol. 2, pp. 2104-2111, 2009.

[36] S. Jadhav, S. Gaikwad, M. Nimse, and A. Rajbhoj, "Copper oxide nanoparticles: synthesis, characterization and their antibacterial activity," Journal of Cluster Science, vol. 22, no. 2, pp. 121-129, 2011.

[37] T. Doolotkeldieva, S. Bobushova, C. Schuster, M. Konurbaeva, and A. Leclerque, "Isolation and genetic characterization of Erwinia amylovora bacteria from Kyrgyzstan," European Journal of Plant Pathology, vol. 155, no. 2, pp. 677-686, 2019.

[38] T. Doolotkeldieva, S. Bobushova, S. Carnal, and F. Rezzonico, "Genetic characterization of Erwinia amylovora isolates detected in the wild walnut-fruit forest of South Kyrgyzstan," Journal of Plant Pathology, vol. 103, no. S1, pp. 109-120, 2021.

[39] J. R. Lamichhane, A. Messéan, and C. E. Morris, "Insights into epidemiology and control of diseases of annual plants caused by the Pseudomonas syringae species complex," Journal of General Plant Pathology, vol. 81, no. 5, pp. 331-350, 2015.

[40] T. Doolotkeldieva and S. Bobusheva, "Characterization of Pseudomonas syringae pv. syringae from diseased stone fruits in Kyrgyzstan and testing of biological agents against pathogen," International Journal of Phytopathology, vol. 9, no. 2, pp. 71-91, 2020.

[41] R. Y. Pelgrift and A. J. Friedman, "Nanotechnology as a therapeutic tool to combat microbial resistance," Advanced Drug Delivery Reviews, vol. 65, no. 13-14, pp. 1803-1815, 2013.

[42] A. D. Pomogailo, "Metal-containing nanocomposites with controlled molecular architecture," Russia Chemical Journal, vol. 21, no. 5, p. 64, 2002, (in Russia).

[43] I. Sondi and B. Salopek-Sondi, "Silver nanoparticles as antimicrobial agent: a case study on _E. coli_as a model for Gramnegative bacteria," Journal of Colloid and Interface Science, vol. 275, no. 1, pp. 177-182, 2004.

[44] T. J. Beveridge, "Structures of gram-negative cell walls and their derived membrane vesicles," Journal of Bacteriology, vol. 181, no. 16, pp. 4725-4733, 1999.

[45] C. Nathan and A. Cunningham-Bussel, "Beyond oxidative stress: an immunologist's guide to reactive oxygen species," Nature Reviews Immunology, vol. 13, no. 5, pp. 349-361, 2013.

[46] E. Pazos-Ortiz, J. H. Roque-Ruiz, E. A. Hinojos-Márquez et al., "Dose-dependent antimicrobial activity of silver nanoparticles on polycaprolactone fibers against Gram-positive and Gramnegative bacteria," Hindawi Journal of Nanomaterials, vol. 2017, article 4752314, 9 pages, 2017.

[47] A. Taglietti, Y. A. Diaz Fernandez, E. Amato et al., "Antibacterial activity of glutathione-coated silver nanoparticles against Gram positive and Gram negative bacteria," Langmuir, vol. 28, no. 21, pp. 8140-8148, 2012.

[48] N. T. Phuong, "Claudiane Ouellet Plamondon," in Nanomaterials Based Coatings, Elsevier, Amsterdam, The Netherlands, 2019.

[49] P. Sharma, D. Bhatt, M. G. Zaidi, P. P. Saradhi, P. K. Khanna, and Y. S. Arora, "Silver nanoparticle-mediated enhancement in growth and antioxidant status of Brassica juncea," Applied Biochemistry and Biotechnology, vol. 167, no. 8, pp. 22252233, 2012.
[50] C. Vannini, G. Domingo, E. Onelli et al., "Morphological and proteomic responses of Eruca sativa exposed to silver nanoparticles or silver nitrate," PLoS One, vol. 8, no. 7, article ???, 2013.

[51] L. Zheng, F. Hong, S. Lu, and C. Liu, "Effect of Nano-TiO< SUB $>2</ S U B>$ on strength of naturally aged seeds and growth of spinach," Biological Trace Element Research, vol. 104, no. 1, pp. 083-092, 2005.

[52] C. M. Lu, C. Y. Zhang, J. Q. Wen, G. R. Wu, and M. X. Tao, "Research of the effect of nanometer materials on germination and growth enhancement of Glycine max and its mechanism," Soybean Science, vol. 21, pp. 168-172, 2002. 